\title{
Sulfur emissions from consumption by developed and developing countries produce comparable climate impacts
}

\author{
Jintai Lin $\rrbracket^{1,12 \bowtie}$, Chunjiang Zhou ${ }^{2,3,4,12}$, Lulu Chen ${ }^{1,12}$, Gang Huang $\mathbb{1}^{2,5,4}{ }^{\natural}$, J.-F. Lamarque ${ }^{6}$, \\ Ji Nie ${ }^{1}$, Jun Yang ${ }^{(1}$, Kaiming Hu ${ }^{7,4}$, Peng Liu ${ }^{1,8}{ }^{1,}$ Jingxu Wang ${ }^{1,9}$, Yan Xia ${ }^{10}$, Yang Yang ${ }^{11}$ and \\ Yongyun $\mathrm{Hu} \mathbb{1}^{1}$
}

Regional consumption activities supported by domestic production and international trade have led to substantial aerosol-related emissions worldwide. Here we quantify sulfur dioxide emissions associated with consumption by developed and developing countries and assess the resulting climate impacts using an Earth system model. We find that although the consumption-associated emissions of developed countries are $40 \%$ less than those of developing countries, they lead to similar impacts on global mean surface air temperature and precipitation. This is because the effective radiative forcing induced per emission is greater for developed countries, which we attribute to the emissions being located at higher northern latitudes and being more evenly distributed zonally. Emissions from developing countries have a greater impact on temperature and precipitation over the tropical monsoon regions of China and India. Our results demonstrate the importance of trade and emission region in determining how consumption translates into global climate impact.

C limate Action and Responsible Consumption and Production are two closely linked Sustainable Development Goals of the United Nations. Consumption activities affect the climate through greenhouse gases and aerosols associated with production to supply consumption. Raw materials extracted to meet global final consumption demands reached 92 billion metric tons in 2017 and will probably increase to 190 billion metric tons by 2060 without concerted action ${ }^{1}$, and extraction, processing, use and disposal of these materials often lead to substantial emissions. Many emission pathways of $1.5^{\circ} \mathrm{C}$ warming require shifts towards sustainable consumption ${ }^{2}$. As international trade allows consumption of any region to be supplied by production worldwide, this affects the magnitude and geographical pattern of consumption-associated emissions ${ }^{3-5}$. Understanding the climate response to consumption-associated emissions offers crucial information to support policymaking and international cooperation in climate change mitigation action from a consumption perspective.

For aerosols, which are short-lived, the spatial distribution of consumption-associated emissions determines the distribution of their atmospheric loadings and thus exerts spatially inhomogeneous forcing ${ }^{6,7}$ to the nonlinear climate system. Emerging evidence has suggested strong nonlinearity in the climate response to the magnitude ${ }^{8,9}$ and location ${ }^{10-13}$ of aerosols. For example, a given amount of aerosol emissions released in Western Europe may cause 14 times as much global average cooling as when emitted in India ${ }^{11}$. These studies are based solely on idealized model experiments by scaling the emissions with an arbitrary factor or by putting the same amount of emissions to different locations. Many studies have analysed the climate impacts of aerosols associated with each region's own production activities and resulting (realistic) emissions ${ }^{14-17}$. The climate response to aerosols associated with the same region's consumption could differ substantially due to the large differences in the magnitude and spatial pattern of emissions and forcing. Yet this consumption-induced climate response has never been assessed explicitly. One recent study has estimated the direct radiative forcing of aerosols embedded in trade ${ }^{6}$, but it does not quantify how such forcing affects temperature and precipitation.

In this article, we provide an assessment of the effects of aerosols from consumption of developed and developing countries on global temperature and precipitation. We quantify the climate response to sulfate aerosol forcing due to consumption-associated emissions of sulfur dioxide $\left(\mathrm{SO}_{2}\right)$ in 2014 , the latest year for which all data and models are available. For this purpose, we combine an emission inventory $^{18}$, a multiregional input-output table ${ }^{19}$ and the fully coupled Community Earth System Model version 2 (CESM2) ${ }^{20}$ (Methods). Identification of developing (including emerging markets) and

\footnotetext{
'Laboratory for Climate and Ocean-Atmosphere Studies, Department of Atmospheric and Oceanic Sciences, School of Physics, Peking University, Beijing, China. ${ }^{2}$ State Key Laboratory of Numerical Modeling for Atmospheric Sciences and Geophysical Fluid Dynamics (LASG), Institute of Atmospheric Physics, Chinese Academy of Sciences, Beijing, China. ${ }^{3}$ School of Ecology and Environment, Inner Mongolia University, Hohhot, China. ${ }^{4}$ University of Chinese Academy of Sciences, Beijing, China. ${ }^{5}$ Laboratory for Regional Oceanography and Numerical Modeling, Qingdao National Laboratory for Marine Science and Technology, Qingdao, China. ${ }^{6}$ Climate and Global Dynamics Laboratory, National Center for Atmospheric Research, Boulder, CO, USA. ${ }^{7}$ Center for Monsoon System Research, Institute of Atmospheric Physics, Chinese Academy of Sciences, Beijing, China. ${ }^{8}$ Frontiers Science Center for Deep Ocean Multispheres and Earth System, Key Lab of Submarine Geosciences and Prospecting Techniques, MOE and College of Marine Geosciences, Ocean University of China, Qingdao, China. ${ }^{9} \mathrm{Key}$ Laboratory of Physical Oceanography, Ocean University of China, Qingdao, China. ${ }^{10} \mathrm{College}$ of Global Change and Earth System Science, Beijing Normal University, Beijing, China. "'Jiangsu Key Laboratory of Atmospheric Environment Monitoring and Pollution Control, Jiangsu Collaborative Innovation Center of Atmospheric Environment and Equipment Technology, School of Environmental Science and Engineering, Nanjing University of Information Science and Technology, Nanjing, China. ${ }^{12}$ These authors contributed equally: Jintai Lin, Chunjiang Zhou,

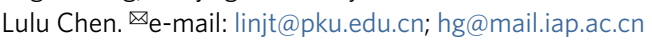


a

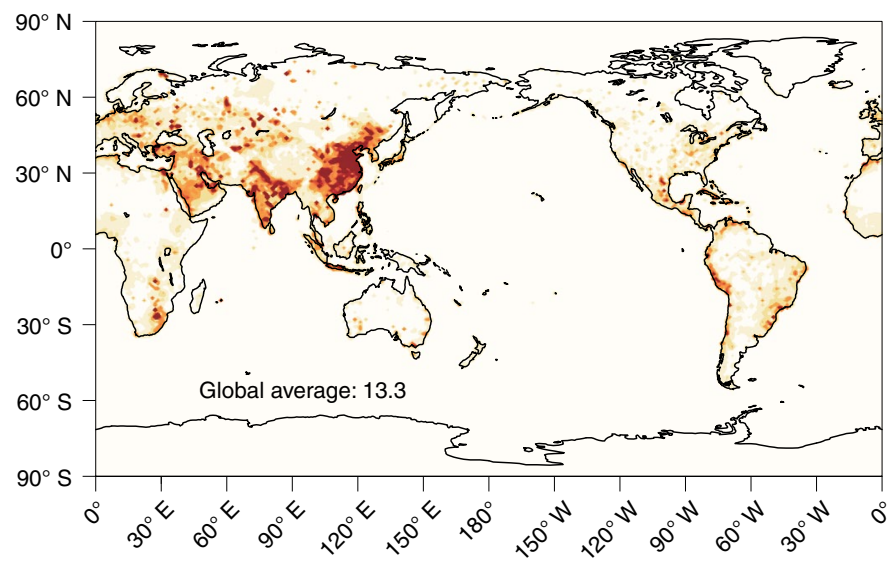

c

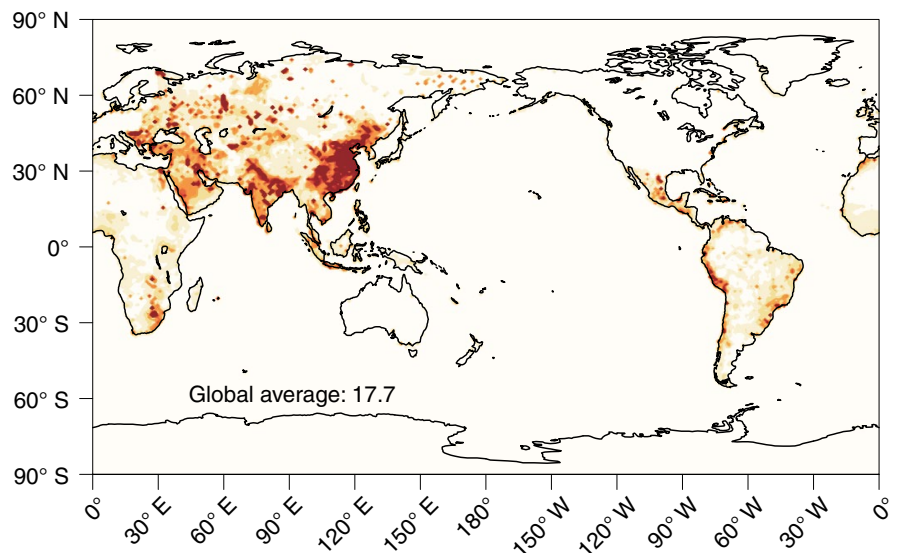

b

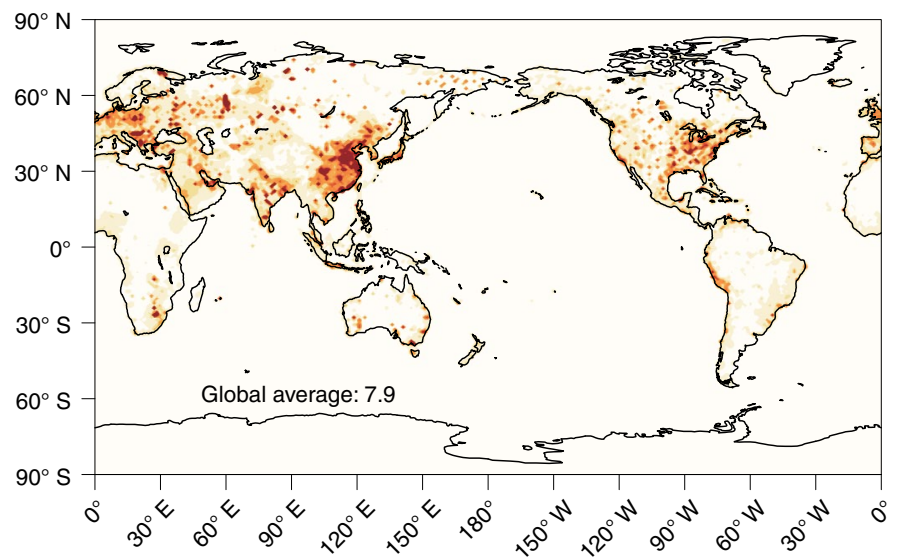

d

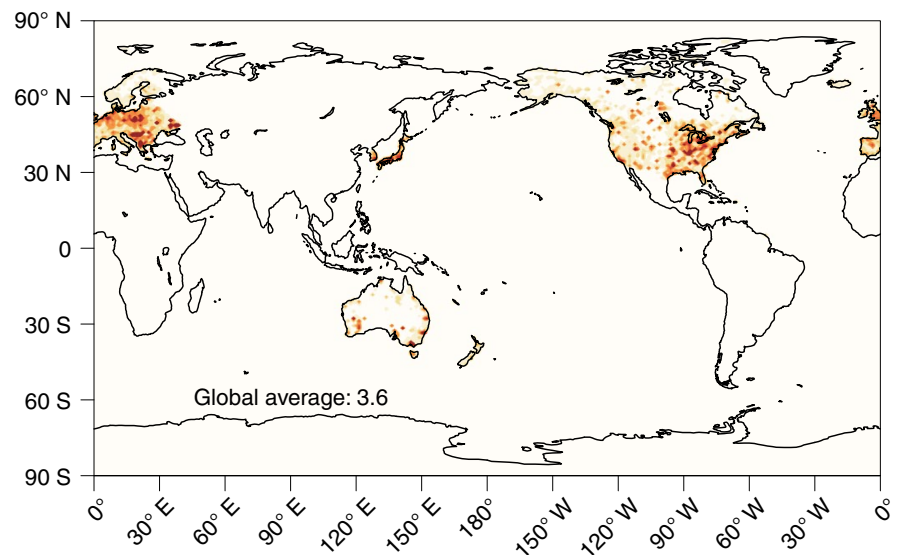

\begin{tabular}{|c|c|c|c|c|c|c|c|c|c|c|}
\hline 0 & 1 & 10 & 30 & 50 & 100 & 150 & 200 & 250 & 300 & 350 \\
\hline
\end{tabular}

Fig. 1 | Contrasting consumption-based and production-based emissions. Anthropogenic $\mathrm{SO}_{2}$ emissions associated with consumption and production activities of developing and developed countries in 2014. $\mathbf{a}, E_{\mathrm{c}}$ of developing countries. b, $E_{\mathrm{c}}$ of developed countries. c, $E_{\mathrm{p}}$ of developing countries. $\mathbf{d}, E_{\mathrm{p}}$ of developed countries. The $E_{c}$ data are calculated in this study, and the $E_{\mathrm{p}}$ data are taken directly from the inventory. The global average is shown in each panel. Map outlines were generated using NCL scripts.

developed countries is based on International Monetary Fund ${ }^{21}$. Uncertainty estimates for global average results are represented by 2 s.d. (corresponding to $95 \%$ confidence interval (CI)), and a paired $z$ test for statistical significance is used to account for autocorrelation $^{22}$. Our results show unexpectedly similar effects of consumption by developed and developing countries on the global average near-surface air temperature and precipitation, despite the large difference in the magnitude of consumption-associated $\mathrm{SO}_{2}$ emissions by a factor of 1.7 .

\section{Consumption-associated sulfur emissions and loadings}

Figure 1 compares the production-based emissions $\left(E_{\mathrm{p}}\right)$ and consumption-based emissions $\left(E_{c}\right)$ of $\mathrm{SO}_{2}$ for both developed and developing countries. The $E_{\mathrm{c}}$ of a region denote worldwide emissions due to production of goods and services to supply consumption by that region. By contrast, the $E_{\mathrm{p}}$ are associated with production by that region to supply global consumption, as recorded in the inventory used here. The global total $E_{\mathrm{c}}$ of developing countries $\left(67.7 \mathrm{Tg} \mathrm{yr}^{-1}\right)$ are about 1.7 times those of developed countries $\left(39.9 \mathrm{Tg} \mathrm{yr}^{-1}\right)$. This is in contrast to the factor-of-five difference in global total $E_{\mathrm{p}}(89.7$ versus $\left.17.8 \mathrm{Tg} \mathrm{yr}^{-1}\right)$. The $E_{\mathrm{c}}$ exhibit much greater spatial coverage than do the $E_{\mathrm{p}}$, especially for the emissions of developed countries (Fig. 1).

Figure 1 further shows that the $E_{\mathrm{c}}$ of developed countries that are released in developing countries are larger than the $E_{\mathrm{c}}$ of developing countries that are released in developed countries by a factor of 7 . These differences are because developed countries are net importers of goods from developing countries and have much lower emission intensities than the latter ${ }^{6,23}$. Overall, the $E_{\mathrm{c}}$ of developing countries are more concentrated in Asia low and middle latitudes, whereas the $E_{c}$ of developed countries more spread out over northern latitudes. These geographical characteristics are further depicted in the zonal average and meridional average emissions in Extended Data Fig. 1. The unique features of regional $E_{c}$ in magnitude and spatial pattern warrant a detailed assessment of resulting climate impacts to supplement prevailing production-based studies.

Extended Data Fig. 2a,b shows the spatial distribution of sulfate aerosol column densities associated with consumption $\left(S_{c}\right)$ by developed and developing countries. Sulfate is formed in the atmosphere from emitted $\mathrm{SO}_{2}$ and lost through dry and wet deposition. The spatial pattern of $S_{c}$ largely follows the $E_{c}$ due to short atmospheric lifetimes of $\mathrm{SO}_{2}$ and sulfate, although portions of sulfate 
Table 1 | Climate response to $E_{c}$ of $\mathrm{SO}_{2}$

$\begin{array}{ll}\begin{array}{l}\text { Due to } E_{\mathrm{c}} \text { of developing } \\ \text { countries }\end{array} & \begin{array}{l}\text { Due to } E_{\mathrm{c}} \text { of developed } \\ \text { countries }\end{array}\end{array}$

\begin{tabular}{|c|c|c|}
\hline $\begin{array}{l}E_{\mathrm{c}}\left(\mathrm{SO}_{2}\right. \\
\left.10^{4} \mu \mathrm{g} \mathrm{m}^{-2} \mathrm{yr}^{-1}\right)\end{array}$ & 13.3 & 7.9 \\
\hline$S_{c}\left(\mathrm{SO}_{4} \mu \mathrm{g} \mathrm{m}^{-2}\right)$ & $17.5( \pm 0.83)$ & $9.1( \pm 0.89)$ \\
\hline$\triangle A O D\left(10^{-2}\right)$ & $0.50( \pm 0.32)$ & $0.32( \pm 0.36)$ \\
\hline $\operatorname{ERF}\left(W_{m^{-2}}\right)$ & $-0.48( \pm 0.64)$ & $-0.42( \pm 0.64)$ \\
\hline$\Delta T(\mathrm{~K})$ & $-0.18( \pm 0.11)$ & $-0.20( \pm 0.09)$ \\
\hline$\Delta P\left(\mathrm{~mm} \mathrm{~d}^{-1}\right)$ & $-0.019( \pm 0.019)$ & $-0.017( \pm 0.017)$ \\
\hline
\end{tabular}

Included are the changes in global average annual mean $S_{c^{\prime}} A O D, E R F, 2 m$ air temperature $(T)$ and precipitation $(P)$. The values in brackets represent 2 s.d.

are transported from emission source regions to downwind areas ${ }^{3}$. The global average $S_{\mathrm{c}}$ of developing countries are 1.9 times the $S_{\mathrm{c}}$ of developed countries, consistent with the difference in $E_{c}$. The $S_{c}$ of developing and developed countries are both large in the Northern Hemisphere (NH), but their regional patterns differ. The $S_{c}$ of developing countries are concentrated over East and South Asia. By comparison, the $S_{c}$ of developed countries are more evenly distributed in the zonal direction at northern latitudes, with high values over Eurasia and North America. The difference in spatial pattern is also evident for aerosol optical depth (AOD, Extended Data Fig. 2c,d).

\section{Climate responses to sulfur emissions}

The $E_{\mathrm{c}}$ of developing and developed countries reduce the global average annual mean $2 \mathrm{~m}$ air temperature by $0.18 \pm 0.11 \mathrm{~K}$ and $0.20 \pm 0.09 \mathrm{~K}$, respectively (Table 1 ). The magnitudes of temperature reduction are both close to the magnitude of observed surface warming $(\sim 0.2 \mathrm{~K})$ over the past decade ${ }^{2}$. The comparable temperature reductions are despite the global average $E_{c}$ and $S_{c}$ of developing countries being 1.7 and 1.9 times those of developed countries. The temperature reduction is most evident in the $\mathrm{NH}$ (Fig. 2a,b), by a hemispheric average of $0.23 \mathrm{~K}$ driven by the $E_{\mathrm{c}}$ of developing countries and by $0.25 \mathrm{~K}$ driven by the $E_{\mathrm{c}}$ of developed countries. The $E_{c}$ of developed countries cause significant cooling at the NH extratropics $\left(30^{\circ}-90^{\circ} \mathrm{N}\right)$ with weak effects over tropical East and South Asia. By comparison, the $E_{\mathrm{c}}$ of developing countries cool East and South Asia but less so at higher latitudes of Eurasia (Fig. 2a). The zonal average results in Fig. 3a,b further show substantial cooling between $60^{\circ} \mathrm{S}$ and $60^{\circ} \mathrm{N}$ by the $E_{c}$ of each region (by $0.10-0.40 \mathrm{~K}$ depending on the latitude). The temperature responses in the polar areas are much more uncertain (Fig. 3 ) due to natural variability ${ }^{14,22}$, although the Arctic cooling induced by the $E_{c}$ of developed countries are statistically significant at $68 \%$ CI.

The unexpectedly comparable cooling effects by the $E_{\mathrm{c}}$ of developing and developed countries are because the $E_{c}$ of developed countries, although smaller in magnitude, have a stronger per-emission capability to induce forcing. To demonstrate this point, we calculate the effective radiative forcing (ERF) of $E_{c}$ with additional Community Atmosphere Model version 6 (CAM6) simulations (Methods). The global mean ERFs due to the $E_{c}$ of developing and developed countries are comparable $(-0.48 \pm 0.64$ versus $-0.42 \pm 0.64 \mathrm{~W} \mathrm{~m}^{-2}$ ), consistent with the similar temperature changes. The ERFs per emission of $\mathrm{SO}_{2}$ for these two regions are $-0.0071 \pm 0.0094$ and $-0.011 \pm 0.016 \mathrm{~W} \mathrm{~m}^{-2}\left(\mathrm{Tg} \mathrm{yr}^{-1}\right)^{-1}$, respectively, with the latter higher by about $50 \%$.

Extended Data Fig. 3a,b further shows the horizontal distribution of ERF. The $E_{c}$ of developed countries lead to significant negative ERF throughout the NH middle and high latitudes, whereas the $E_{c}$ of developing countries result in the greatest ERF at the low and middle latitudes around China and India. The negative ERF caused by $E_{c}$ of developing countries is statistically significant at $95 \% \mathrm{CI}$ over South Asia, East Asia and the downwind northern Pacific, significant at $68 \%$ CI over the majority of the $\mathrm{NH}$ but insignificant over the contiguous United States (Extended Data Fig. 3a). The negative ERF by $E_{c}$ of developed countries is statistically significant at $95 \% \mathrm{CI}$ over parts of East Asia, the northern Pacific, northern Eurasia and North America and significant at $68 \%$ CI over many other $\mathrm{NH}$ areas (Extended Data Fig. 3b).

Decomposition of the ERF by using radiative kernels ${ }^{24}$ shows major contributions from the direct radiative forcing of sulfate and fast adjustment of clouds, with minor effects from fast adjustments of other climate variables (Extended Data Table 1). The spatial distribution of sulfate direct radiative forcing (Extended Data Fig. 3c,d) follows those of $S_{c}$ and AOD (Extended Data Fig. 2), with the global average sulfate forcing induced by the $E_{\mathrm{c}}$ of developing countries 2.5 times that of developed countries $(-0.16 \pm 0.031$ versus $-0.066 \pm 0.026 \mathrm{~W} \mathrm{~m}^{-2}$ ). The $E_{\mathrm{c}}$ of developing and developed countries exert similar global average radiative effects via fast cloud adjustment $\left(-0.32 \pm 0.70\right.$ versus $-0.32 \pm 0.72 \mathrm{~W} \mathrm{~m}^{-2}$, Extended Data Table 1). The fast cloud adjustment corresponds to the overall increase in clouds coverage (statistically significant at $95 \%$ or $68 \%$ CI over large regions; Extended Data Fig. 4).

Extended Data Table 2 shows radiative kernel decomposition ${ }^{24}$ for the top-of-atmosphere (TOA) net radiative flux resulting from $E_{\mathrm{c}}$ perturbation, as averaged over the past 110 years of fully coupled CESM2 simulations. Contributors to the net flux include ERF and the resulting responses of water vapour, surface albedo, temperature and clouds. The contributions of all non-ERF factors are in addition to the radiative effects of their fast adjustments presented in Extended Data Table 1. The 110-year average net fluxes due to the $E_{\mathrm{c}}$ of developing and developed countries are much smaller than the respective values of ERF. Over the 110 years, the net flux is varying but with no trends (Supplementary Fig. 3). The net flux is not zero because the response of deep ocean to ERF (which may take thousands of years) has not been fully realized; this is evident from the imbalance in surface energy flux over the oceans (Extended Data Fig. 3e,f).

Extended Data Table 2 shows that the ERF-induced reduction in surface temperature (in addition to the small fast adjustment) leads to a large positive radiative effect, whereas the corresponding reduction in water vapour leads to a negative radiative effect. The ERF-induced change in clouds (in addition to the fast adjustment) leads to a small radiative effect. The total radiative effect of clouds change induced by $E_{\mathrm{c}}$ of each region is negative $\left(-0.23 \pm 1.26 \mathrm{~W} \mathrm{~m}^{-2}\right.$ for developing countries and $-0.26 \pm 1.43 \mathrm{~W} \mathrm{~m}^{-2}$ for developed countries), calculated as the sum of the respective values in Extended Data Tables 1 and 2. This is consistent with the overall enhancement in clouds coverage simulated by fully coupled CESM2 (statistically significant at $95 \%$ or $68 \%$ CI over vast areas; Extended Data Fig. 5).

In the Arctic areas, the $E_{c}$ of developed countries lead to an increase in sea-ice coverage (Extended Data Fig. 6b) and a deepened polar vortex (as manifested in the geopotential height and wind field at $500 \mathrm{hPa}$, Extended Data Fig. 7b). The increase in sea ice coincides with the strong surface cooling there (Fig. 2b). The change in polar vortex is consistent with the widespread cooling over the northern middle and high latitudes (Fig. 2b). By comparison, the $E_{\mathrm{c}}$ of developing countries lead to weaker Arctic responses (Extended Data Figs. $6 \mathrm{a}$ and $7 \mathrm{a}$ ) because the emissions are located at lower latitudes.

The $E_{c}$ of developing and developed countries each result in warming along the coasts of Greenland. The temperature change is consistent with the reduction in sea-ice coverage (Extended Data Fig. 6a,b) and the increase in the surface (latent + sensible) heat flux to the atmosphere (Extended Data Fig. 6e,f). Correspondingly, the change in surface winds reduces the sea-ice drift to these locations (Extended Data Fig. 6c,d).

In the tropics, the Southern Hemisphere (SH) Hadley cell circulation strengthens and the NH Hadley cell weakens, and the associ- 
a

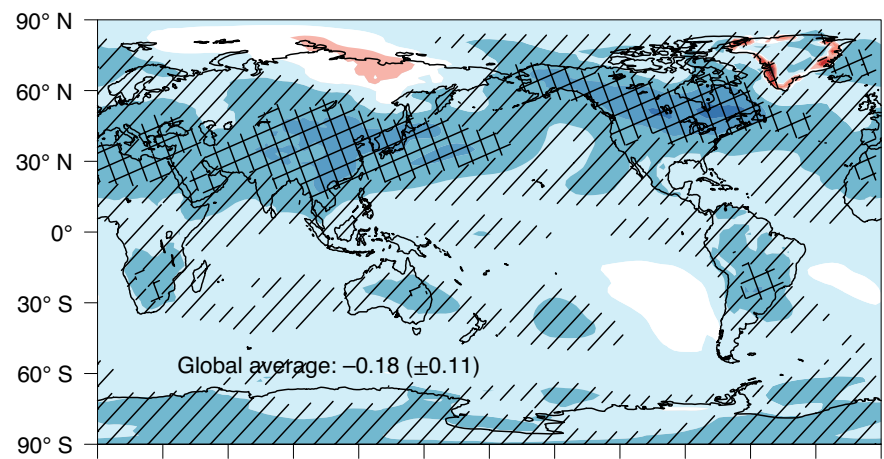

$90^{\circ} \mathrm{S}$

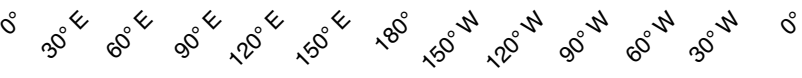

$$
\begin{aligned}
& \begin{array}{llllll}
-1.00 & -0.80 & -0.60 & -0.40 & -0.20 & -0.05
\end{array}
\end{aligned}
$$

C

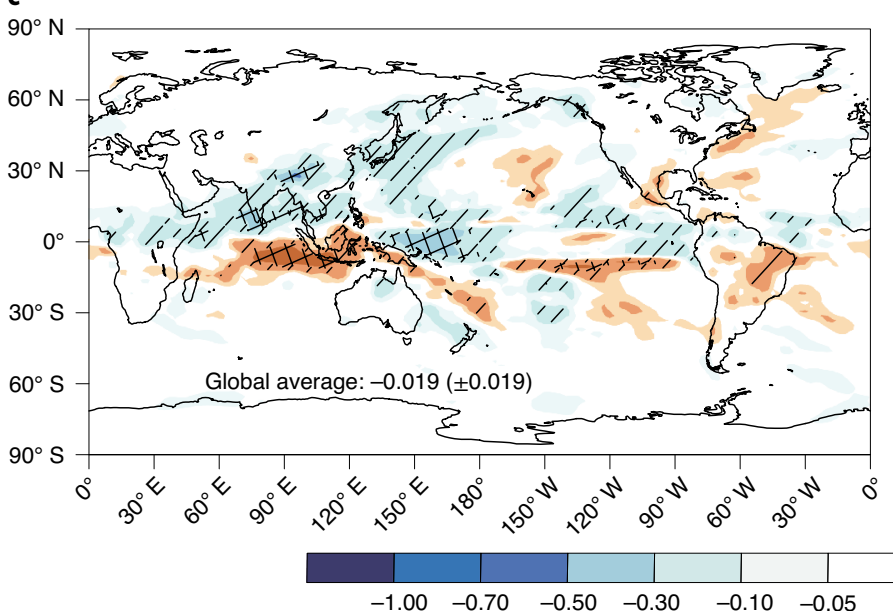

b

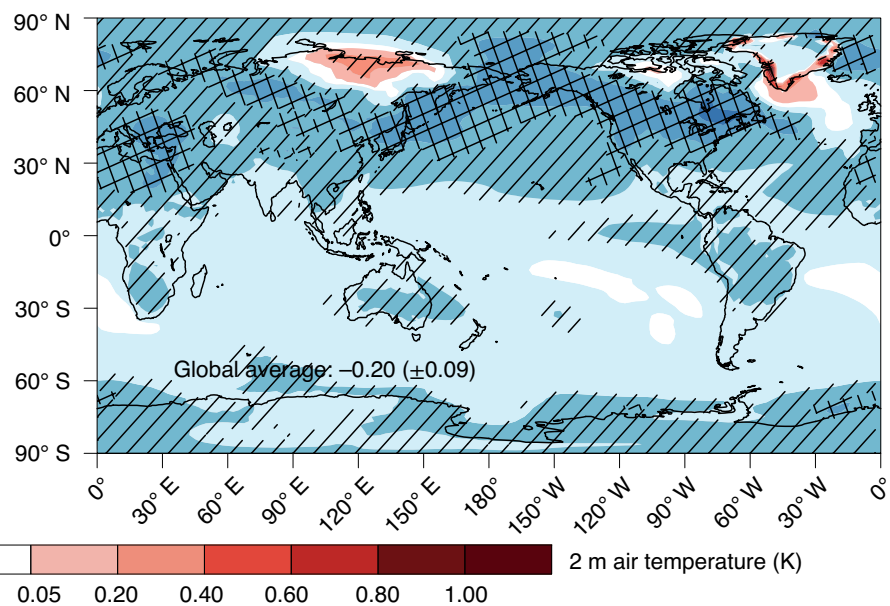

d

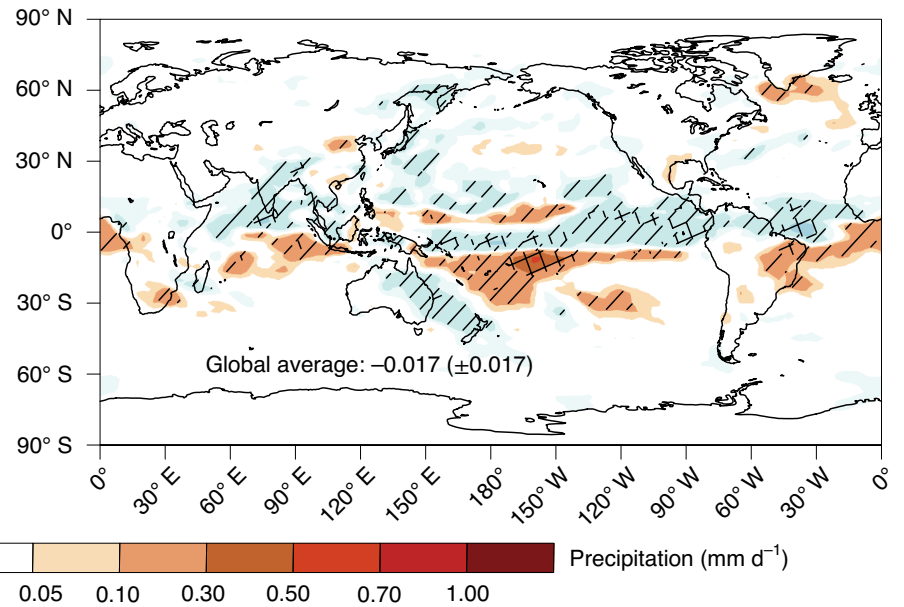

Fig. 2 | Climate response to consumption-based emissions. a, Changes in annual mean 2 m air temperature due to $E_{c}$ of developing countries. b, Changes in annual mean $2 \mathrm{~m}$ air temperature due to $E_{c}$ of developed countries. $\mathbf{c}$, Changes in precipitation due to $E_{c}$ of developing countries. $\mathbf{d}$, Changes in precipitation due to $E_{c}$ of developed countries. The grid cells with cross lines pass the paired $z$ test at $95 \% \mathrm{Cl}$, and those with diagonal lines pass the test at $68 \% \mathrm{Cl}$. The global average is shown in each panel. Map outlines were generated using NCL scripts.

ated intertropical convergence zone shifts southwards, as manifested in the weakened rising in the $\mathrm{NH}$ tropics and enhanced rising in the SH tropics (Extended Data Fig. 8). These tropical responses are because the sulfate-induced cooling is stronger in the $\mathrm{NH}$ than in the $\mathrm{SH}$, resulting in reduced hemispheric temperature asymmetry (because the $\mathrm{NH}$ is warmer than the $\mathrm{SH}$ climatologically) and less atmospheric cross-Equator energy transport to the $\mathrm{SH}$ by the Hadley cell ${ }^{25,26}$. The tropical circulation change is associated with weakened precipitation ${ }^{27,28}$ in South and East Asian monsoon areas (Fig. 2c,d), which has a warming effect ${ }^{29}$ that partly offsets the radiative cooling effect. Since the magnitude of ERF by developing countries is large in East and South Asia (Extended Data Fig. 3a), the sinking enhancement at $0-20^{\circ} \mathrm{N}$ is strong (Extended Data Fig. 8a). The ERF by developed countries occurs at higher latitudes and is zonally evener. The resulting effect on the Hadley cell is weaker in magnitude (Extended Data Fig. 8b versus 8a), as also reflected in the weaker change in meridional winds in tropical Asian monsoon areas at $850 \mathrm{hPa}$ (Extended Data Fig. 7d versus 7c).

The $E_{c}$ of developing and developed countries result in similar reductions in global average annual mean precipitation $\left(-0.019 \pm 0.019\right.$ versus $-0.017 \pm 0.017 \mathrm{~mm} \mathrm{~d}^{-1}$, Fig. $\left.2 c, d\right)$ since the response of precipitation is strongly constrained by radiative energy balance $^{30}$. The calculated changes in precipitation are statistically significant at $68 \%$ CI over the majority of tropical oceans. The precipitation changes are even statistically significant at $95 \%$ over parts of the tropical regions of China, India, the Indian Ocean and the western Pacific due to the $E_{c}$ of developing countries (Fig. 2c) and over parts of the tropical Pacific due to the $E_{\mathrm{c}}$ of developed countries (Fig. 2d). The $E_{\mathrm{c}}$ of developing countries result in the greatest reduction (by up to $0.57 \mathrm{~mm} \mathrm{~d}^{-1}$, statistically significant at $95 \%$ CI; Fig. 2c) over tropical Asian continental monsoon areas (India, IndoChina Peninsula and south China), whereas the $E_{c}$ of developed countries do not cause such a strong reduction (Fig. $2 \mathrm{c}, \mathrm{d}$ ). The zonal average results also show the strongest precipitation changes in the tropics (by up to about $\pm 0.1 \mathrm{~mm} \mathrm{~d}^{-1}$ ), with a reduction in the $\mathrm{NH}$ and an enhancement in the SH (Fig. 3c,d), consistent with the changes in the Hadley cell and intertropical convergence zone (Extended Data Fig. 8). The peak zonal average precipitation enhancement over the SH tropics is statistically significant at $68 \% \mathrm{CI}$.

\section{A consumption-based perspective for climate action}

For each region, there exist substantial differences between its $E_{\mathrm{c}}$ and $E_{\mathrm{p}}$ in the magnitude and geographical pattern. The climate response to emissions associated with regional consumption presented in this study is very different from that inferred from prevailing production-based studies. For example, applying the global 


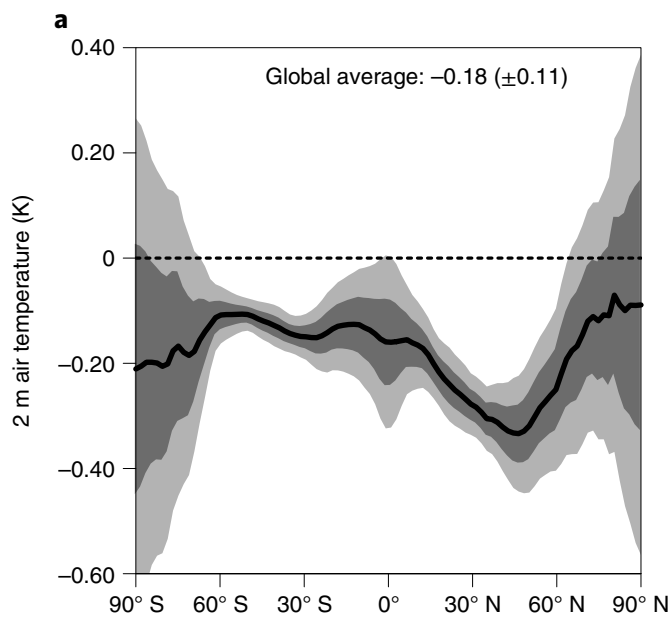

c

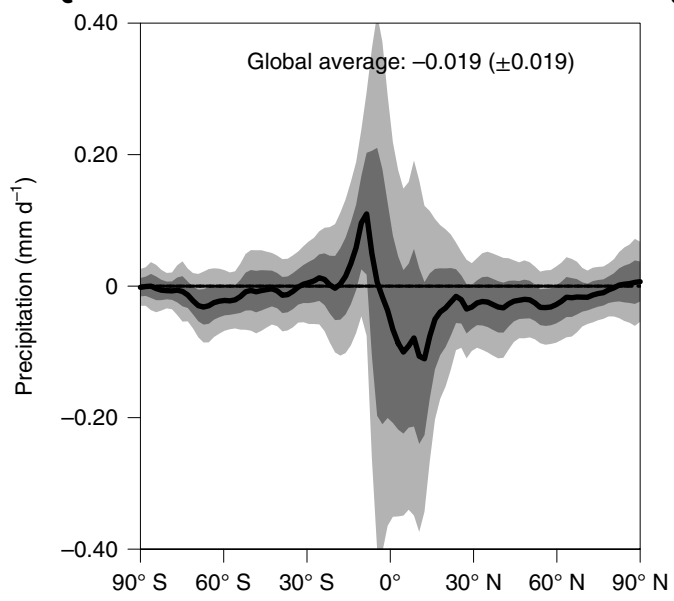

b

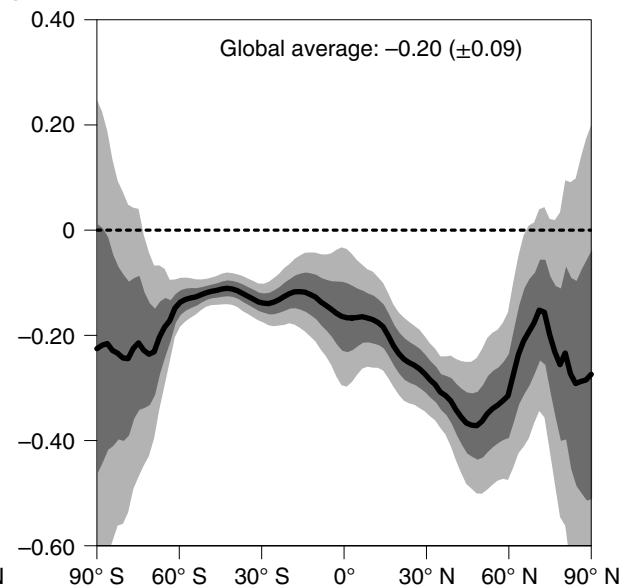

d

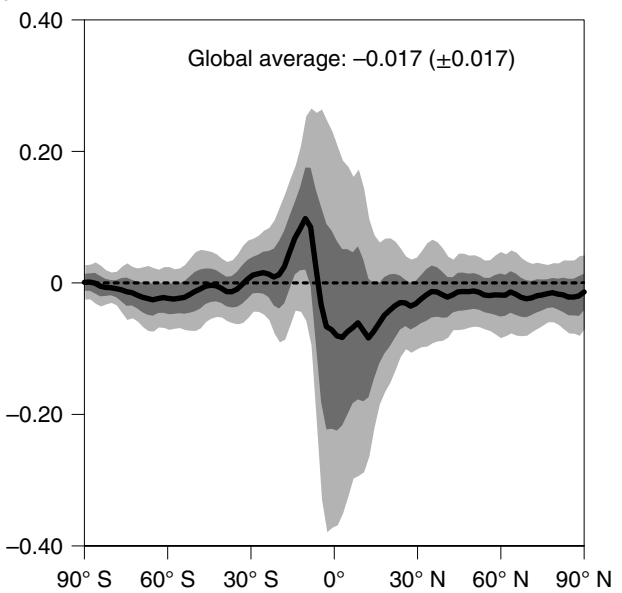

Fig. 3 | Zonal average climate response to consumption-based emissions. a, Changes in zonal average annual mean $2 \mathrm{~m}$ air temperature in response to $E_{c}$ of developing countries. $\mathbf{b}$, Changes in zonal average annual mean $2 \mathrm{~m}$ air temperature in response to $E_{c}$ of developed countries. $\mathbf{c}$, Changes in precipitation in response to $E_{\mathrm{c}}$ of developing countries. d, Changes in precipitation in response to $E_{\mathrm{c}}$ of developed countries. The light shading indicates $2 \mathrm{~s}$.d. of the $110 \mathrm{yr}$ time series, and the dark shading indicates 1 s.d. The global average value is shown in each panel.

average temperature change per unit of $E_{\mathrm{p}}$ suggested by ref. ${ }^{9}$ would mean a factor-of-five difference in the temperature response to the $E_{\mathrm{p}}$ of developing and developed countries, in contrast to the comparable temperature effects by their $E_{c}$ shown here. This suggests that a picture of the regional contribution to climate change drawn from both production and consumption perspectives will be more complete in supporting regional efforts to combat climate change.

Although the $E_{c}$ of $\mathrm{SO}_{2}$ by developing and developed countries differ by a factor of 1.7, they result in comparable changes in the global average surface air temperature and precipitation. This highlights the complex response of the nonlinear climate system to not only the magnitude but also the spatial pattern of aerosols. This finding is broadly consistent with previous $E_{\mathrm{p}}$-based, idealized model simulations ${ }^{8-13}$, although our results are based on realistic $E_{c}$ emissions. For climate policy considerations and international negotiations, a climate change attribution assessment based on fully coupled model simulations driven by realistic, regionally detailed emissions is important. Such an assessment will also offer a reference to validate and correct results based on simplified metrics (for example, global average radiative forcing and global warming potential) in situations where these metrics are used to save computational resources and time.

Our study is based on emissions in a recent year. Along with the economic globalization and trade liberation, the world has expe- rienced rapid changes in regional $E_{\mathrm{p}}$ and $E_{\mathrm{c}}$. The $E_{\mathrm{p}}$ of developed countries have continued to decline for decades ${ }^{18}$, but their $E_{\mathrm{c}}$ have declined at much weaker rates ${ }^{3,31}$. Over the recent few years, the $E_{\mathrm{p}}$ of China have been reduced substantially ${ }^{32}$, whereas the $E_{\mathrm{p}}$ of many developing countries have continued to grow or changed little $^{33,34}$ (except for the temporary disruption by COVID-19), and the resulting changes in $E_{\mathrm{c}}$ remain unclear. Future changes in $E_{\mathrm{p}}$ and $E_{c}$ will depend on the pathway of socioeconomic development and emission control. Many future scenarios assume transition in the energy-industrial sector at a scale not experienced in the past ${ }^{2,35}$. A few ongoing events such as the Sino-US trade war $^{23}$, Brexit and COVID-19 have disrupted the global trade, but the duration of these events and their direct and indirect emissions impacts are less clear. Also not clear are whether the world will embrace continuous globalization-regional rivalry is one of the few plausible shared socioeconomic pathways projected for this century ${ }^{36}$ - and how this will affect the magnitude and distribution of regional $E_{\mathrm{c}}$. These pose important questions of how the continuously changing $E_{c}$ of each region have been affecting and will affect the climate system.

Our study is focused on the effect of sulfate. However, consumption activities also affect other aerosols (for example, black carbon) and greenhouse gases. Given the importance of responsible consumption to the success of climate change mitigation and environmental protection ${ }^{1,2}$, it will be very beneficial to conduct a com- 
prehensive assessment of the climate response to the whole suite of climate-relevant constituents associated with regional consumption. A multimodel assessment will help reduce the intrinsic uncertainty in model simulations. This, of which our sulfate study serves as the first step, will complement prevailing production-based analyses to help understand how human activities affect the climate system more thoroughly. As much of the $E_{\mathrm{c}}$ of any region are released in other regions, such a consumption-based assessment will also provide a basis for international cooperation to act towards sustainable consumption and climate change mitigation, which will have substantial co-benefits for public health ${ }^{4}$.

\section{Online content}

Any methods, additional references, Nature Research reporting summaries, source data, extended data, supplementary information, acknowledgements, peer review information; details of author contributions and competing interests; and statements of data and code availability are available at https://doi.org/10.1038/ s41561-022-00898-2.

Received: 15 July 2020; Accepted: 10 January 2022; Published online: 17 February 2022

\section{References}

1. The Sustainable Development Goals Report (United Nations, 2019); https:// unstats.un.org/sdgs/report/2019/

2. IPCC: Summary of Policymakers. In Special Report on Global Warming of $1.5^{\circ} \mathrm{C}$ (eds Masson-Delmotte, V. et al.) (WMO, 2018).

3. Lin, J.-T. et al. Retrieving tropospheric nitrogen dioxide from the ozone monitoring instrument: effects of aerosols, surface reflectance anisotropy, and vertical profile of nitrogen dioxide. Atmos. Chem. Physics 14, 1441-1461 (2014)

4. Zhang, Q. et al. Transboundary health impacts of transported global air pollution and international trade. Nature 543, 705-709 (2017).

5. Wiedmann, T. \& Lenzen, M. Environmental and social footprints of international trade. Nat. Geosci. 11, 314-321 (2018).

6. Lin, J. et al. Global climate forcing of aerosols embodied in international trade. Nat. Geosci. 9, 790-794 (2016).

7. Wang, J.-X. et al. Socioeconomic and atmospheric factors affecting aerosol radiative forcing: production-based versus consumption-based perspective. Atmos. Environ. 200, 197-207 (2019).

8. Yang, Y., Smith, S. J., Wang, H., Mills, C. M. \& Rasch, P. J. Variability, timescales, and nonlinearity in climate responses to black carbon emissions. Atmos. Chem. Physics 19, 2405-2420 (2019).

9. Lewinschal, A. et al. Local and remote temperature response of regional $\mathrm{SO}_{2}$ emissions. Atmos. Chem. Physics 19, 2385-2403 (2019).

10. Shindell, D. \& Faluvegi, G. Climate response to regional radiative forcing during the twentieth century. Nat. Geosci. 2, 294-300 (2009).

11. Persad, G. G. \& Caldeira, K. Divergent global-scale temperature effects from identical aerosols emitted in different regions. Nat. Commun. 9, 3289 (2018).

12. Sand, M., Berntsen, T. K., Ekman, A. M. L., Hansson, H.-C. \& Lewinschal, A. Surface temperature response to regional black carbon emissions: do location and magnitude matter? Atmos. Chem, Physics 20, 3079-3089 (2020).

13. Liu, L. et al. A PDRMIP multimodel study on the impacts of regional aerosol forcings on global and regional precipitation. J. Clim. 31, 4429-4447 (2018).
14. Westervelt, D. M. et al. Multimodel precipitation responses to removal of US sulfur dioxide emissions. J. Geophys. Res. 122, 5024-5038 (2017).

15. Acosta Navarro, J. C. et al. Amplification of Arctic warming by past air pollution reductions in Europe. Nat. Geosci. 9, 277-281 (2016).

16. Li, B. et al. The contribution of China's emissions to global climate forcing. Nature 531, 357-361 (2016).

17. Menon, S., Hansen, J., Nazarenko, L. \& Luo, Y. Climate effects of black carbon aerosols in China and India. Science 297, 2250-2253 (2002).

18. Hoesly, R. M. et al. Historical (1750-2014) anthropogenic emissions of reactive gases and aerosols from the Community Emissions Data System (CEDS). Geosci. Model Dev. 11, 369-408 (2018).

19. GTAP Version 10 (Pre-Released Version) (Purdue Univ., 2019); https://www. gtap.agecon.purdue.edu/about/project.asp

20. Danabasoglu, G. et al. The Community Earth System Model Version 2 (CESM2). J. Adv. Model. Earth Syst. https://doi.org/10.1029/2019ms001916 (2020).

21. World Economic Outlook (IMF, 2011).

22. Conley, A. J. et al. Multimodel surface temperature responses to removal of US sulfur dioxide emissions. J. Geophys. Res. 123, 2773-2796 (2018).

23. Lin, J. et al. Carbon and health implications of trade restrictions. Nat Commun. 10, 4947 (2019).

24. Huang, Y., Xia, Y. \& Tan, X. On the pattern of $\mathrm{CO}_{2}$ radiative forcing and poleward energy transport. Geophys. Res. Atmos. 122, 10578-10593 (2017).

25. Kang, S. M., Held, I. M., Frierson, D. M. W. \& Zhao, M. The response of the ITCZ to extratropical thermal forcing: idealized slab-ocean experiments with a GCM. J. Clim. 21, 3521-3532 (2008).

26. Schneider, T., Bischoff, T. \& Haug, G. H. Migrations and dynamics of the intertropical convergence zone. Nature 513, 45-53 (2014).

27. Ganguly, D., Rasch, P. J., Wang, H. \& Yoon, J.-H. Climate response of the South Asian monsoon system to anthropogenic aerosols. J. Geophys. Res. https://doi.org/10.1029/2012jd017508 (2012).

28. Song, F., Zhou, T. \& Qian, Y. Responses of East Asian summer monsoon to natural and anthropogenic forcings in the 17 latest CMIP5 models. Geophys. Res. Lett. 41, 596-603 (2014).

29. Mueller, B. \& Seneviratne, S. I. Hot days induced by precipitation deficits at the global scale. Proc. Natl Acad. Sci. USA 109, 12398-12403 (2012).

30. Held, I. M. \& Soden, B. J. Robust responses of the hydrological cycle to global warming. J. Clim. 19, 5686-5699 (2006).

31. Kanemoto, K., Moran, D., Lenzen, M. \& Geschke, A. International trade undermines national emission reduction targets: new evidence from air pollution. Glob. Environ. Change 24, 52-59 (2014).

32. Zheng, B. et al. Trends in China's anthropogenic emissions since 2010 as the consequence of clean air actions. Atmos. Chem. Physics 18, 14095-14111 (2018).

33. McDuffie, E. E. et al. A global anthropogenic emission inventory of atmospheric pollutants from sector- and fuel-specific sources (1970-2017): an application of the Community Emissions Data System (CEDS). Earth Syst. Sci. Data Discuss. https://doi.org/10.5194/essd-2020-103 (2020).

34. Chen, L.-L. et al. Inequality in historical transboundary anthropogenic PM2.5 health impacts. Sci. Bull. https://doi.org/10.1016/j.scib.2021.11.007 (2021).

35. Shindell, D. \& Smith, C. J. Climate and air-quality benefits of a realistic phase-out of fossil fuels. Nature 573, 408-411 (2019).

36. Riahi, K. et al. The shared socioeconomic pathways and their energy, land use, and greenhouse gas emissions implications: an overview. Glob. Environ. Change 42, 153-168 (2017).

Publisher's note Springer Nature remains neutral with regard to jurisdictional claims in published maps and institutional affiliations.

(c) The Author(s), under exclusive licence to Springer Nature Limited 2022 


\section{Methods}

An interdisciplinary framework. Through an interdisciplinary framework, we employ sector-, region- and pollutant-specific anthropogenic emission data from the Community Emissions Data System (CEDS) inventory for the Coupled Model Intercomparison Project phase 6 (CMIP6) project ${ }^{18}$, use the latest Global Trade Analysis Project (GTAP) multiregional input-output (MRIO) table (version 10 for 2014) $)^{19}$ to estimate consumption-related emissions of $\mathrm{SO}_{2}$, and run the fully coupled CESM $2^{20}$ to simulate the climate impacts of such sulfur emissions. The widely used ${ }^{4,6,23}$ GTAP MRIO table offers quantitative information on the inter-sectoral and inter-regional economic linkage along the global supply chain and tracks worldwide production activities in support of consumption of each region. The MRIO table together with the CEDS CMIP6 emission inventory allows for an estimate of consumption-based emissions. Such emissions are then implemented into the fully coupled CESM2 for climate impact simulations, supplemented by additional atmosphere-only simulations.

The CESM2 Model. We use fully coupled CESM2 in this study. CESM2 is the most current-generation Earth system model developed by the National Center for Atmospheric Research and other institutions. CESM2 is built on many successes of its predecessor, CESM1.2, which is one of the best models in the CMIP5 set of model simulations according to a pattern distance metric of present-day precipitation and temperature ${ }^{37,38}$. CESM1.2 captures the spatial pattern of climatic surface temperature at a country scale in the meteorological reanalysis data, with a high correlation coefficient and a low normalized mean deviation ${ }^{39}$ CESM2 contains many updates to CEMS1.2 and results in an improved historical simulation, including a better representation of low-latitude precipitation and shortwave cloud forcing ${ }^{20}$. An overview of CESM2 can be found elsewhere ${ }^{20}$.

CAM6 is the atmospheric component of CESM2. Inside CAM6, we choose a fully interactive aerosol scheme, the Modal Aerosol Model version 4 (MAM4) ${ }^{40}$, following the CESM2 set-up for submission to CMIP6. The main difference between MAM4 and the MAM3 scheme used in CESM1.2 is the representation of carbonaceous aerosols ${ }^{40}$. $\mathrm{SO}_{2}$ is oxidized by the hydroxyl radical, hydrogen peroxide and ozone to form sulfate $\left(\mathrm{SO}_{4}\right)$, and sulfate size distributions are simulated prognostically in three lognormal modes: Aitken, accumulation and coarse ${ }^{41,42}$. Both MAM4 and MAM3 provide aerosol simulations with reasonable agreement with observations ${ }^{43,44}$; and they have been used widely to simulate the effects of sulfate on global temperature, precipitation and local climate ${ }^{11,14,22,45-51}$. In this study, CAM6 is run at a horizontal resolution of $1.9^{\circ} \times 2.5^{\circ}$ with 32 vertical levels.

CESM2 includes an interactive land surface model (the Community Land Model version 5 $)^{52}$ run at the same horizontal resolution as CAM6, with an extensive suite of new and updated processes and parameterizations to previous versions. The ocean component of CESM2 adopts the Parallel Ocean Program version $2(\mathrm{POP} 2)^{53}$ with several physics and numerical improvements ${ }^{20}$ and is run at an equivalent resolution of $1^{\circ}$. CESM2 uses the Los Alamos sea-ice model version 5.1.2 (CICE5) $)^{54}$ as its sea-ice component, and CICE5 shares the same horizontal grid with POP2.

Supplementary Fig. 1a describes the suite of model simulations in this study. We conduct three cases of fully coupled CESM2 simulations, including GLOBAL, Xdeveloping CE and Xdeveloped_CE. The three cases differ only in anthropogenic $\mathrm{SO}_{2}$ emissions, with global emissions in GLOBAL, removal of $E_{\mathrm{c}}$ of developing countries in Xdeveloping_CE and removal of $E_{\mathrm{c}}$ of developed countries in Xdeveloped_CE. The impacts of consumption by developing and developed countries are obtained by subtracting simulation results of Xdeveloping_CE and Xdeveloped_CE from GLOBAL, respectively.

Before running the three cases, we conduct an additional fully coupled simulation Pre_run for 300 years from an initial climate state in the year 2000. The GLOBAL case then starts from the climate state in the 300th year of the Pre_run and continues for an additional 407 years; Supplementary Fig. 2 shows that the climate has reached quasi-equilibrium state at this time. Xdeveloping_CE contains three ensemble members branched from the 201st, 211th and 265th years of GLOBAL, respectively. Xdeveloped_CE contains three ensemble members branched from the 201st, 235th and 247th years of GLOBAL, respectively. Each ensemble member of Xdeveloping_CE and X_developed_CE is run for 140 years, with the last 110 years used for analysis. Depending on the years of each ensemble member of Xdeveloping_CE and X_developed_CE, results from GLOBAL are paired temporally for comparison.

Each simulation outputs monthly mean values for temperature, precipitation and other variables. For Xdeveloping_CE or X_developed_CE, each of the three ensemble members provides a monthly time series of paired difference relative to GLOBAL, and the three resulting time series are averaged to obtain an ensemble mean time series. The $110 \mathrm{yr}$ average and standard deviation for the ensemble mean time series are analysed. To correct for the model autocorrelation, we apply the paired $z$ test $^{22}$ to the monthly time series and focus the analysis on areas where the climate response passes the significance test with respect to $95 \%$ or $68 \%$ CI.

Effective radiative forcing calculations. The ERF represents the change in the TOP net (shortwave + longwave) radiative flux due to emission perturbations and fast adjustments of the atmosphere and land surface, with sea surface temperature and sea ice unchanged.
To calculate the ERF, we conduct three additional simulations of CAM6 with specified sea surface temperature and sea ice, following ref. ${ }^{22}$. Here, the ERF is computed from individual simulations with $\mathrm{SO}_{2}$ emissions identical to GLOBAL, Xdeveloping_CE or X_developed_CE. An all-emission CAM6 simulation is run for 199 years. Other simulations branch from the fifth year of the all-emission simulation and are run for 195 years. The last 190 years of all simulations are used to calculate the ERF

Radiative kernel decomposition. We calculate the TOA radiative feedbacks using the radiative kernel method introduced by ref. ${ }^{24}$, which has been widely used in decomposition of radiative effects for climate change analysis ${ }^{5-61}$. The radiative kernel, $K_{X}$, is pre-calculated by a partial perturbation method using the radiative transfer model RRTM ${ }^{62}$ for temperature $(T)$, water vapour $(q)$ and surface albedo (a). Then, for non-cloud climate variables, the radiative feedback is computed as

$$
\Delta_{X} R=K_{X} \Delta X
$$

for $X=T, q$ or $a$. The direct radiative forcing $(G)$ from sulfate is calculated on the basis of CAM6 simulations, as determined by contrasting the TOA radiative flux (calculated at each time step but outputted every month) from CAM6 simulations with and without the $E_{\mathrm{c}}$ (GLOBAL versus Xdeveloping_CE or GLOBAL versus X_developed_CE). The cloud feedback is then obtained from the residual of the radiation budget

$$
\Delta_{\text {cld }} R=\Delta R-\mathrm{G}-K_{T} \Delta \mathrm{T}-K_{q} \Delta q-K_{a} \Delta a
$$

where $\Delta R$ is the response of the net TOA radiative flux.

Emissions. In a globalized economy with regions and sectors inter-connected through trade, the difference between $E_{\mathrm{p}}$ and $E_{\mathrm{c}}$ lies in the attribution of emissions associated with production to supply consumption. For example, a cell phone sold in the United States may be assembled in China with steel produced in Japan and iron ore extracted in Australia, and all associated emissions are allocated to the United States from the consumption perspective $\left(E_{c}\right)$ but to these individual countries from the production perspective $\left(E_{\mathrm{p}}\right)$.

Anthropogenic emissions of all species but $\mathrm{SO}_{2}$ represent the year 2000, as taken from the CESM2 present-day simulations. Emissions of $\mathrm{SO}_{2}$ for the year 2014 are obtained by combining the (production-based) CEDS CMIP6 inventory ${ }^{18}$ and the latest version (v.10, for 2014) of the widely used ${ }^{4,6,23}$ GTAP MRIO table ${ }^{19}$.

The GTAP MRIO table is a result of an internationally collaborative effort to produce a regionally and sectorally harmonized, high-quality input-output database for global trade analysis. It has been widely used as a core dataset in general equilibrium models. The disaggregation details of regions and sectors in the GTAP v.10 table are compatible with those in CEDS, with sectoral and regional mapping established in previous work ${ }^{23,63}$.

The calculation of $\mathrm{SO}_{2} E_{\mathrm{c}}$ follows our previous studies ${ }^{4,6,23}$ and is briefly described here (see the flow chart in Supplementary Fig. 1b). We first obtain the worldwide $E_{\mathrm{p}}$ of $\mathrm{SO}_{2}$ in 2014 from the CEDS CMIP6 emissions inventory, which specifies monthly emissions for 55 sectors on a $0.5^{\circ} \times 0.5^{\circ}$ horizontal grid. We also calculate the production and consumption (each in monetary quantity) in 57 sectors of 141 countries/regions on the basis of the GTAP v.10 MRIO table for 2014. Production of each country/region and sector is to supply direct and indirect consumption by all regions and sectors. GTAP provides quantitative information of the linkages between sectors and regions along the global supply chain. The mapping from 55 sectors in CEDS to 57 sectors in GTAP follows ref. (see their supplementary data 6). We then calculate country- and sector-specific emission intensities (emission divided by monetary economic output) of $\mathrm{SO}_{2}$ on the basis of the $E_{\mathrm{p}}$ and production data. We further calculate the $E_{\mathrm{c}}$ of individual countries/regions and sectors by multiplying the sectoral emission intensities with consumption-associated sectoral output. Within each country, the spatial and monthly distributions of $E_{\mathrm{c}}$ follow the distributions of the corresponding $E_{\mathrm{p}}$. For example, the $E_{c}$ of the United States that are released in China (due to Chinese production for US consumption) follow the spatial and monthly distributions of the $E_{\mathrm{p}}$ of China. For consumption activities not associated with monetary economic output such as residential use and private vehicle driving (and thus not shown in the GTAP MRIO table), emissions are taken from the CEDS CMIP6 dataset directly, following ref. ${ }^{23}$.

\section{Data availability}

The GTAP data are available at https://www.gtap.agecon.purdue.edu/. The CEDS CMIP6 emissions are available at https://esgf-node.llnl.gov/search/input4mips/. Model results that support the findings of this study are available on Zenodo with the identifier https://doi.org/10.5281/zenodo.5722962. Raw model simulation results generated during this study are large in size and are available upon reasonable request. Source data are provided with this paper.

\section{Code availability}

The CESM is available at http://www.cesm.ucar.edu/models/cesm2/. The codes for kernel calculation are available at http://www.meteo.mcgill.ca/ huang/. Data 
analysis and visualizations are created by the NCAR Command Language, which is freely available at https://doi.org/10.5065/D6WD3XH5. All computer codes generated during this study are available from the corresponding authors upon reasonable request.

\section{References}

37. Knutti, R., Masson, D. \& Gettelman, A. Climate model genealogy: generation CMIP5 and how we got there. Geophys. Res. Lett. 40, 1194-1199 (2013).

38. Gettelman, A. et al. High climate sensitivity in the Community Earth System Model version 2 (CESM2). Geophys. Res. Lett. 46, 8329-8337 (2019).

39. Zheng, Y., Davis, S. J., Persad, G. G. \& Caldeira, K. Climate effects of aerosols reduce economic inequality. Nat. Clim. Change 10, 220-224 (2020)

40. Liu, X. et al. Description and evaluation of a new four-mode version of the Modal Aerosol Module (MAM4) within version 5.3 of the Community Atmosphere Model. Geosci. Model Dev. 9, 505-522 (2016).

41. Liu, X. et al. Toward a minimal representation of aerosols in climate models: description and evaluation in the Community Atmosphere Model CAM5. Geosci. Model Dev. 5, 709-739 (2012).

42. Emmons, L. K. et al. The chemistry mechanism in the Community Earth System Model version 2 (CESM2). J. Adv. Model. Earth Syst. https://doi. org/10.1029/2019ms001882 (2020).

43. Tilmes, S. et al. Description and evaluation of tropospheric chemistry and aerosols in the Community Earth System Model (CESM1.2). Geosci. Model Dev. 8, 1395-1426 (2015).

44. Mills, M. J. et al. Global volcanic aerosol properties derived from emissions, 1990-2014, using CESM1(WACCM). J. Geophys. Res. Atmos. 121, 2332-2348 (2016).

45. Kasoar, M. et al. Regional and global temperature response to anthropogenic $\mathrm{SO}_{2}$ emissions from China in three climate models. Atmos. Chem. Physics 16, 9785-9804 (2016).

46. Yang, Y., Wang, H., Smith, S. J., Easter, R. C. \& Rasch, P. J. Sulfate aerosol in the Arctic: source attribution and radiative forcing. J. Geophys. Res. 123, 1899-1918 (2018).

47. Westervelt, D. M. et al. Local and remote mean and extreme temperature response to regional aerosol emissions reductions. Atmos. Chem. Physics 20, 3009-3027 (2020)

48. Undorf, S., Bollasina, M. A., Booth, B. B. B. \& Hegerl, G. C. Contrasting the effects of the 1850-1975 increase in sulphate aerosols from North America and Europe on the Atlantic in the CESM. Geophys. Res. Lett. 45, 11,930-911,940 (2018).

49. Jiang, Y., Yang, X.-Q. \& Liu, X. Seasonality in anthropogenic aerosol effects on East Asian climate simulated with CAM5. J. Geophys. Res. Atmos. 120 10837-10861 (2015).

50. Zhao, A., Stevenson, D. S. \& Bollasina, M. A. Climate forcing and response to greenhouse gases, aerosols, and ozone in CESM1. J. Geophys. Res. 124, 13876-13894 (2019).

51. Zhou, C. et al. The impact of secondary inorganic aerosol emissions change on surface air temperature in the Northern Hemisphere. Theor. Appl. Climatol. https://doi.org/10.1007/s00704-020-03249-6 (2020).

52. Lawrence, D. M. et al. The Community Land Model version 5: description of new features, benchmarking, and impact of forcing uncertainty. J. Adv. Model. Earth Syst. 11, 4245-4287 (2019).

53. Smith, R. et al. The Parallel Ocean Program (POP) Reference Manual. Ocean Component of the Community Climate System Model (CCSM) and Community Earth System Model (CESM) Technical Report LAUR-10-01853 (Los Alamos National Laboratory, 2010).

54. Hunke, E. C., Hebert, D. A. \& Lecomte, O. Level-ice melt ponds in the Los Alamos sea ice model, CICE. Ocean Model. 71, 26-42 (2015). 71.

55. Xia, Y. et al. Significant contribution of severe ozone loss to the Siberian-Arctic surface warming in spring 2020. Geophys. Res. Lett. 48, e2021GL092509 (2021).
56. Xia, Y. et al. Stratospheric ozone-induced cloud radiative effects on Antarctic sea ice. Adv. Atmos. Sci. 37, 505-514 (2020).

57. Xia, Y., Huang, Y. \& Hu, Y. On the climate impacts of upper tropospheric and lower stratospheric ozone. J. Geophys. Res. Atmos. 123, 730-739 (2018).

58. Zelinka, M. D. et al. Causes of higher climate sensitivity in CMIP6 models. Geophys. Res. Lett. 47, e2019GL085782 (2020).

59. Sherwood, S. C. et al. An assessment of Earth's climate sensitivity using multiple lines of evidence. Rev. Geophys. 58, e2019RG000678 (2020).

60. Harrop, B. E., Lu, J., Liu, F., Garuba, O. A. \& Leung, L. R. Sensitivity of the ITCZ location to ocean forcing via q-flux Green's function experiments. Geophys. Res. Lett. 45, 13116-13123 (2018).

61. Xia, Y. \& Huang, Y. Differential radiative heating drives tropical atmospheric circulation weakening. Geophys. Res. Lett. 44, 10592-10600 (2017).

62. Mlawer, E. J., Taubman, S. J., Brown, P. D., Iacono, M. J. \& Clough, S. A. Radiative transfer for inhomogeneous atmospheres: RRTM, a validated correlated-k model for the longwave. J. Geophys. Res. Atmos. 102, 16663-16682 (1997).

63. Du, M. et al. Winners and losers of the Sino-US trade war from economic and environmental perspectives. Environ. Res. Lett. https://doi. org/10.1088/1748-9326/aba3d5 (2020).

\section{Acknowledgements}

We thank M. Mills, H. Wang, X. Li and Z. Lu for help with model set-up at the beginning of the project and Y. Liu for discussion. This work is funded by the National Natural Foundation of China $(42075175,41831175,41775115)$ and the Second Tibetan Plateau Scientific Expedition and Research (2019QZKK0604, 2019QZKK0102), the Key Deployment Project of Centre for Ocean Mega-Research of Science, the Chinese Academy of Sciences (COMS2019Q03) and the Strategic Priority Research Program of the Chinese Academy of Sciences (XDA20060501). Y.H. is supported by the National Natural Science Foundation (41888101). J.W. is supported by the Fundamental Research Funds for the Central Universities (202113005) and the Natural Science Foundation of Shandong Province (ZR2021QD119). P.L. is supported by the National Natural Science Foundation of China (42105043) and China Postdoctoral Science Foundation (2021M690142 and 2021T140629).

\section{Author contributions}

J.L. and G.H. conceived the study. J.L. and C.Z. designed the research. L.C. calculated the emissions. C.Z. conducted the CAM and CESM simulations. P.L., J.W. and Y.Y. contributed to the experiments. Y.X. conducted radiative kernel calculations. J.L., C.Z., G.H., J.-F.L., J.N., J.Y. and K.H. analysed the results. J.L. and C.Z. wrote the paper with comments from J.-F.L., J.N., J.Y., K.H. and Y.H.

\section{Competing interests}

The authors declare no competing interests.

\section{Additional information}

Extended data is available for this paper at https://doi.org/10.1038/s41561-022-00898-2.

Supplementary information The online version contains supplementary material available at https://doi.org/10.1038/s41561-022-00898-2.

Correspondence and requests for materials should be addressed to Jintai Lin or Gang Huang.

Peer review information Nature Geoscience thanks Geeta Persad, S. Ramachandran and Manfred Lenzen for their contribution to the peer review of this work. Primary Handling Editor: Tom Richardson, in collaboration with the Nature Geoscience team.

Reprints and permissions information is available at www.nature.com/reprints. 


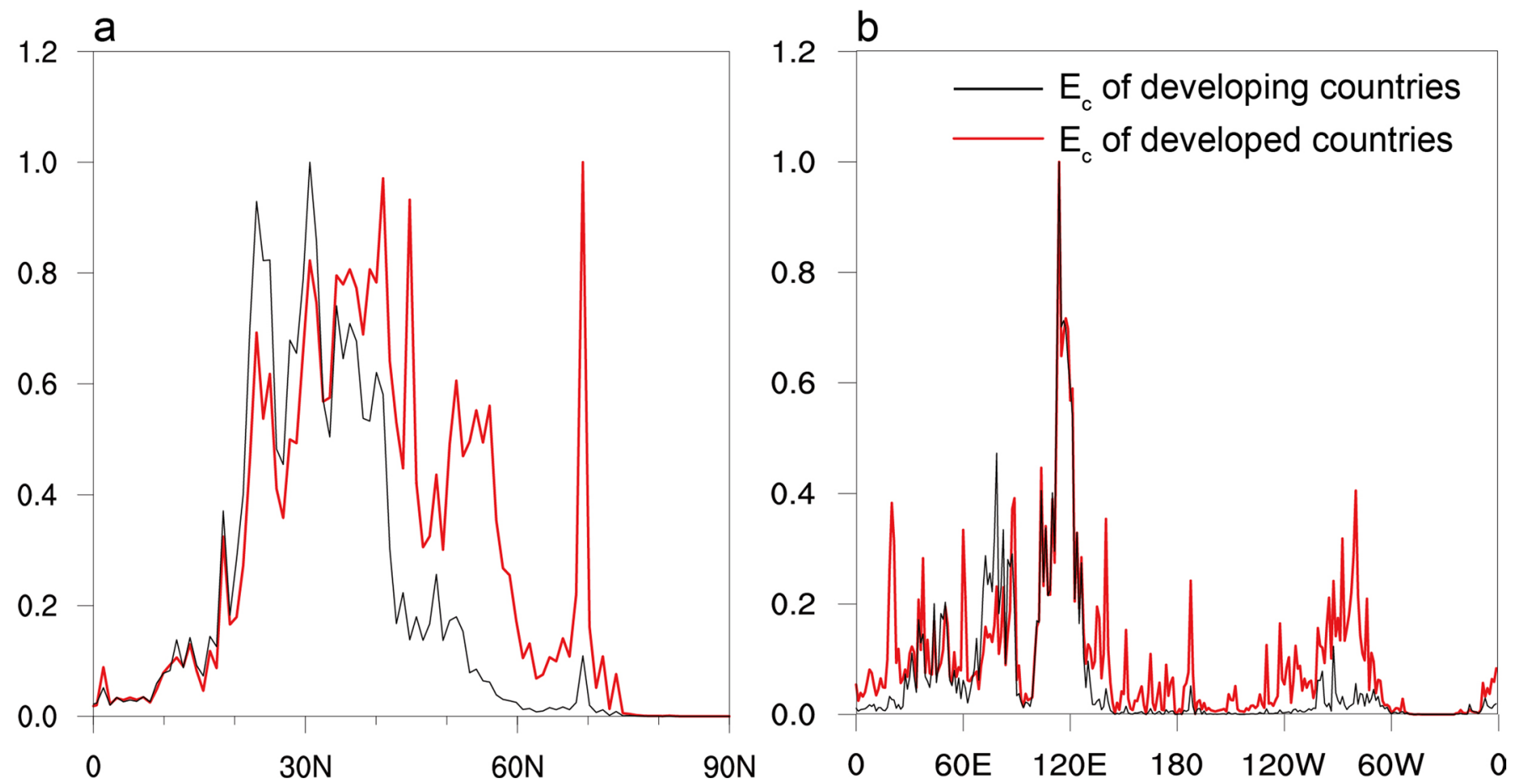

Extended Data Fig. 1 | Latitudinal and longitudinal variations of emissions in the Northern Hemisphere. Zonal average $E_{c}(a)$ by developing and developed countries, and meridional average $\mathrm{E}_{c}(\mathrm{~b})$. Emission values are averaged over land and then normalized relative to their min-max value. 


\section{Due to $E_{c}$ of developing countries}

a

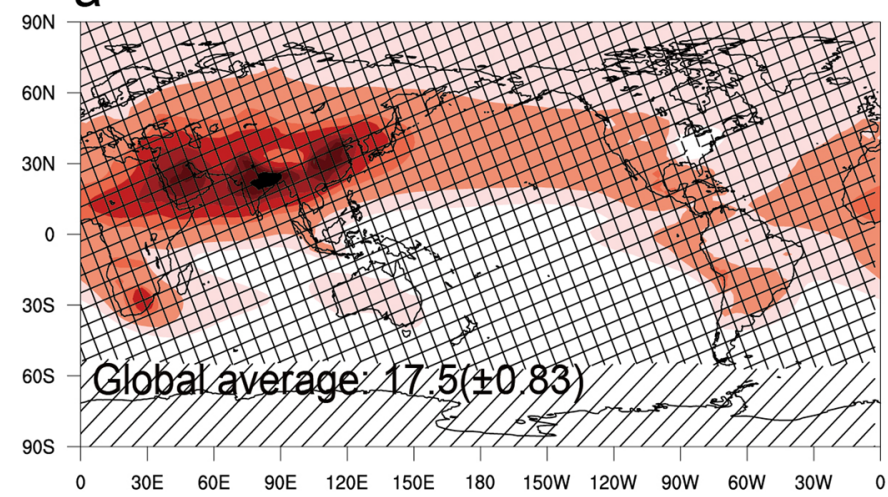

b

\section{Due to $E_{c}$ of developed countries}

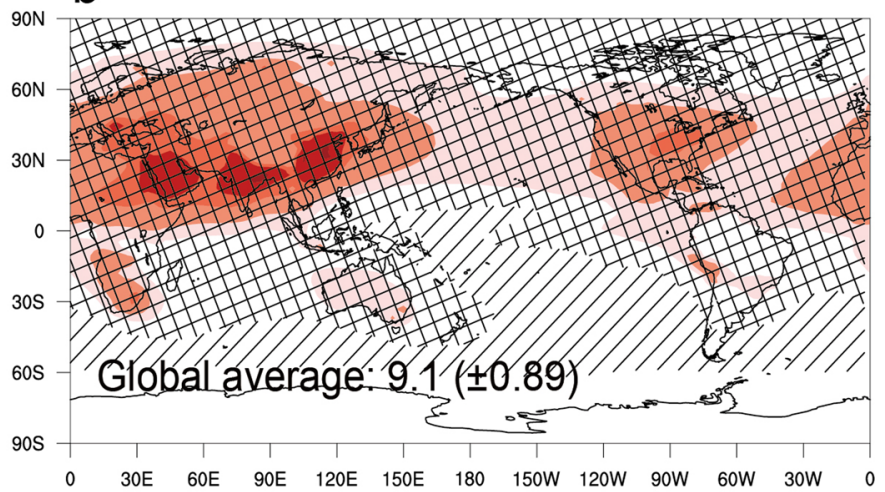

\begin{tabular}{ll|llllllll}
\hline & $\mid$ & $\mid$ & $\mid$ & $\mid$ & $\mid$ & & & & \\
\hline & 5 & 10 & 30 & 50 & 100 & 150 & 200 & 250 & Sulfate column concentrations $\left(\mu \mathrm{g} / \mathrm{m}^{2}\right)$
\end{tabular}

C

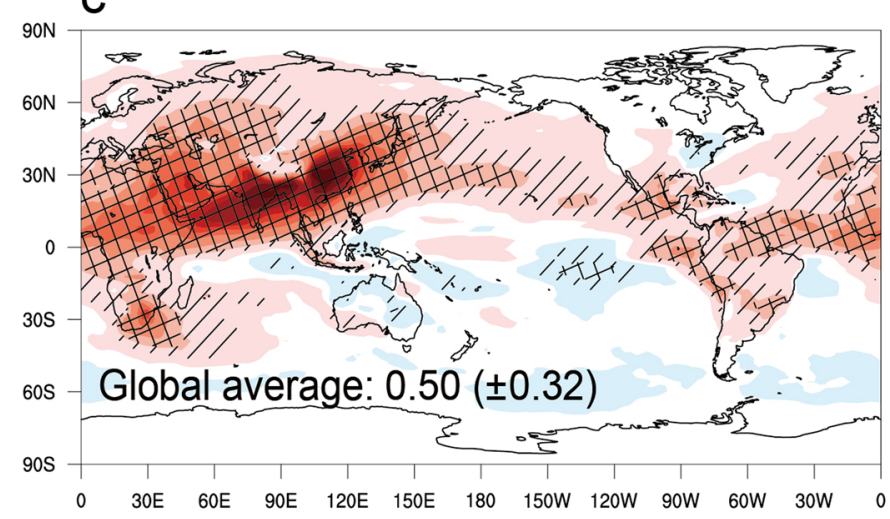

d

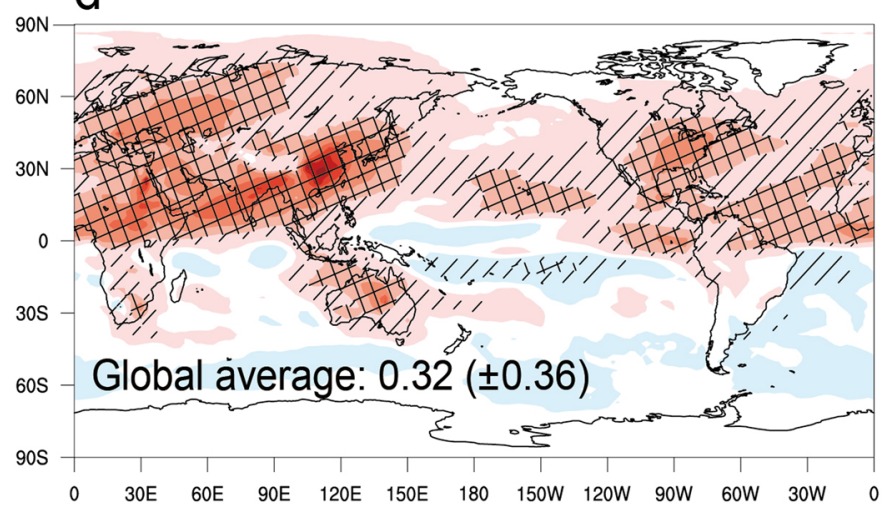

\begin{tabular}{c|c|c|c|c|c|c|c|c|c|}
\hline & $\mid$ & $\mid$ & $\mid$ & $\mid$ & $\mid$ & & & \\
\hline
\end{tabular}

Extended Data Fig. 2 | Sulfate and AOD responses to consumption-based emissions. Changes in annual mean $S_{c}(a, b)$ and $A O D(c, d)$ due to $E_{c}$ of developing and developed countries. AOD includes the effect of all aerosol compositions. The grid cells with cross lines pass the paired $z$-test at $95 \% \mathrm{Cl}$ and those with diagonal lines pass the test at $68 \% \mathrm{Cl}$. The global average with 2 standard deviations is shown in each panel. 
a

\section{Due to $E_{c}$ of developing countries}

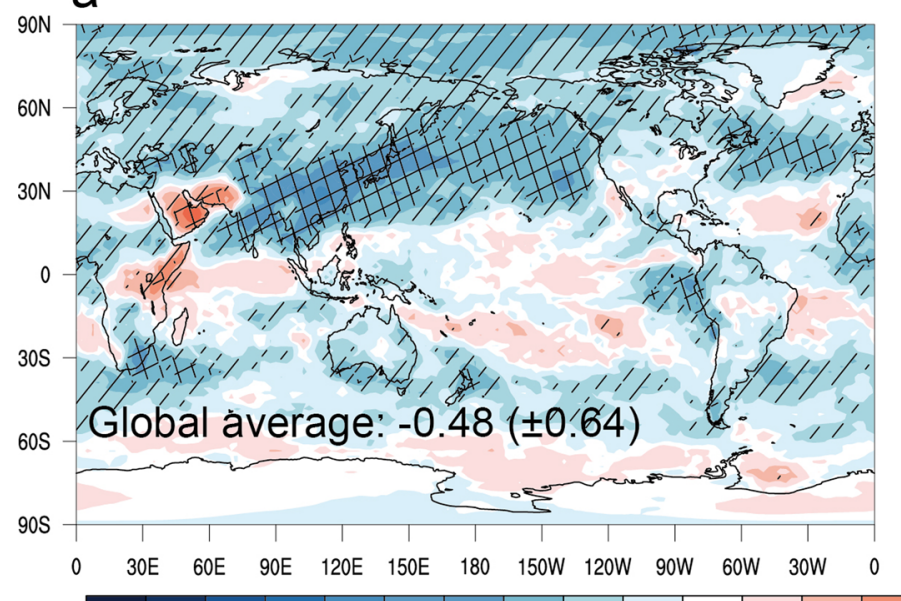

b

\section{Due to $E_{c}$ of developed countries}

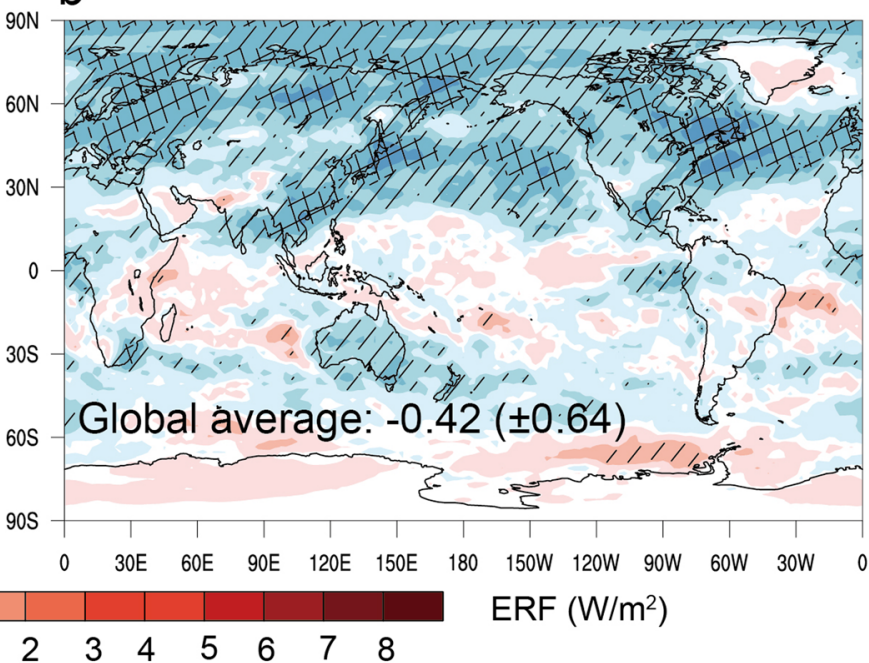

C
$\begin{array}{llllllllllllllllll}-8 & -7 & -6 & -5 & -4 & -3 & -2 & -1 & -0.5 & -0.1 & 0.1 & 0.5 & 1\end{array}$

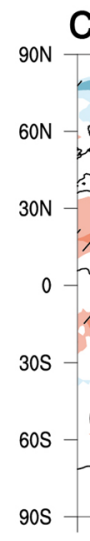

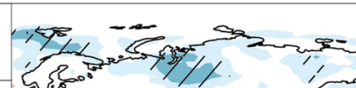

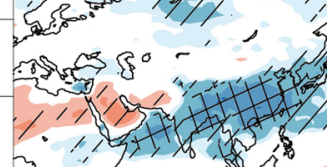

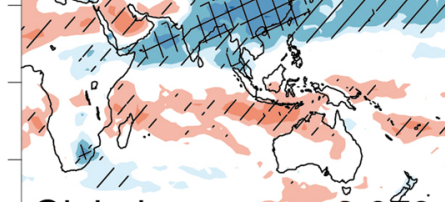

Global average: $-0.073( \pm 0.50)$

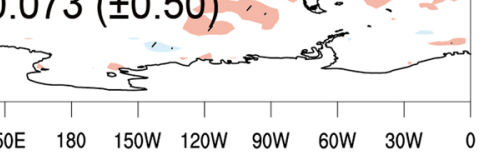

$0 \quad 30 \mathrm{E} \quad 60 \mathrm{E} \quad 90 \mathrm{E} \quad 120 \mathrm{E} \quad 150 \mathrm{E} \quad 180 \quad 150 \mathrm{~W} \quad 120 \mathrm{~W}$ 90W $60 \mathrm{~W}$ 30W

\section{d}

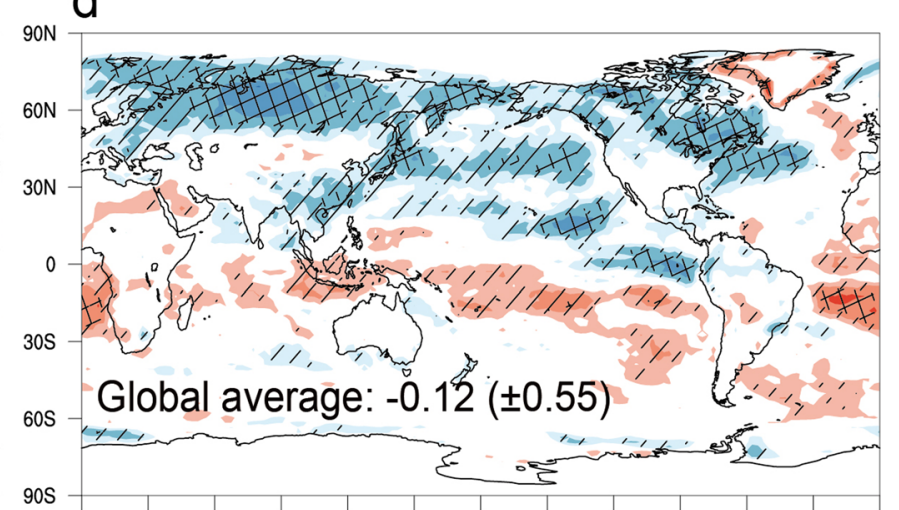

$\begin{array}{llllllllllllll}0 & 30 \mathrm{E} & 60 \mathrm{E} & 90 \mathrm{E} & 120 \mathrm{E} & 150 \mathrm{E} & 180 & 150 \mathrm{~W} & 120 \mathrm{~W} & 90 \mathrm{~W} & 60 \mathrm{~W} & 30 \mathrm{~W} & 0\end{array}$

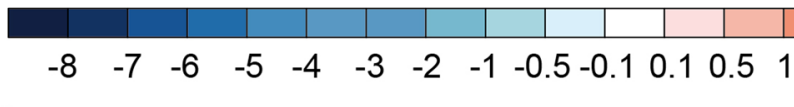

2

$\mathrm{SW}+\mathrm{LW}$ radiation flux at TOA

$\left(\mathrm{W} / \mathrm{m}^{2}\right)$
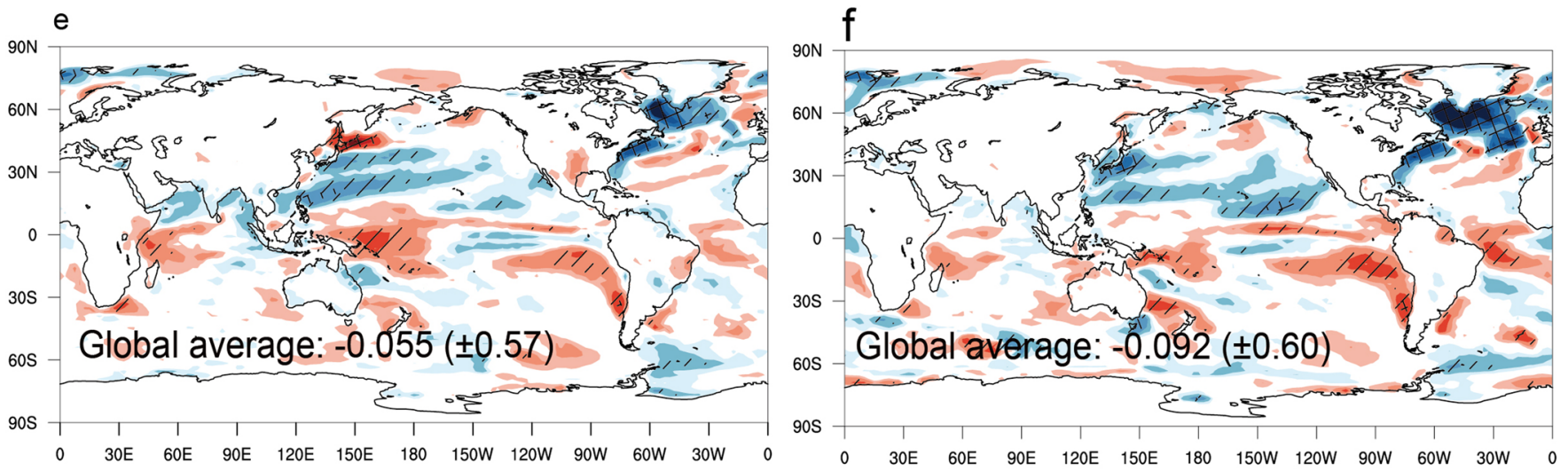

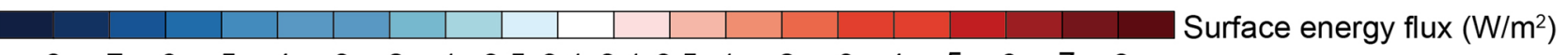

\section{$\begin{array}{lllllllllllllllllllll}-8 & -7 & -6 & -5 & -4 & -3 & -2 & -1 & -0.5 & -0.1 & 0.1 & 0.5 & 1 & 2 & 3 & 4 & 5 & 6 & 7 & 8\end{array}$}

Extended Data Fig. 3 | Energy imbalance induced by consumption-based emissions. (a,b) Annual mean ERF due to $E_{c}$ of developing and developed countries calculated based on CAM6 simulations. (c-f) Annual mean TOA net radiative flux (shortwave + longwave; c,d) and surface energy flux (shortwave + longwave + latent heat + sensible heat; e,f) due to $E_{c}$ of developing and developed countries calculated based on fully coupled CESM2 simulations. The grid cells with cross lines pass the paired z-test at $95 \% \mathrm{Cl}$ and those with diagonal lines pass the test at $68 \% \mathrm{Cl}$. The global average with 2 standard deviations is shown in each panel. 


\section{Due to $E_{c}$ of developing countries}
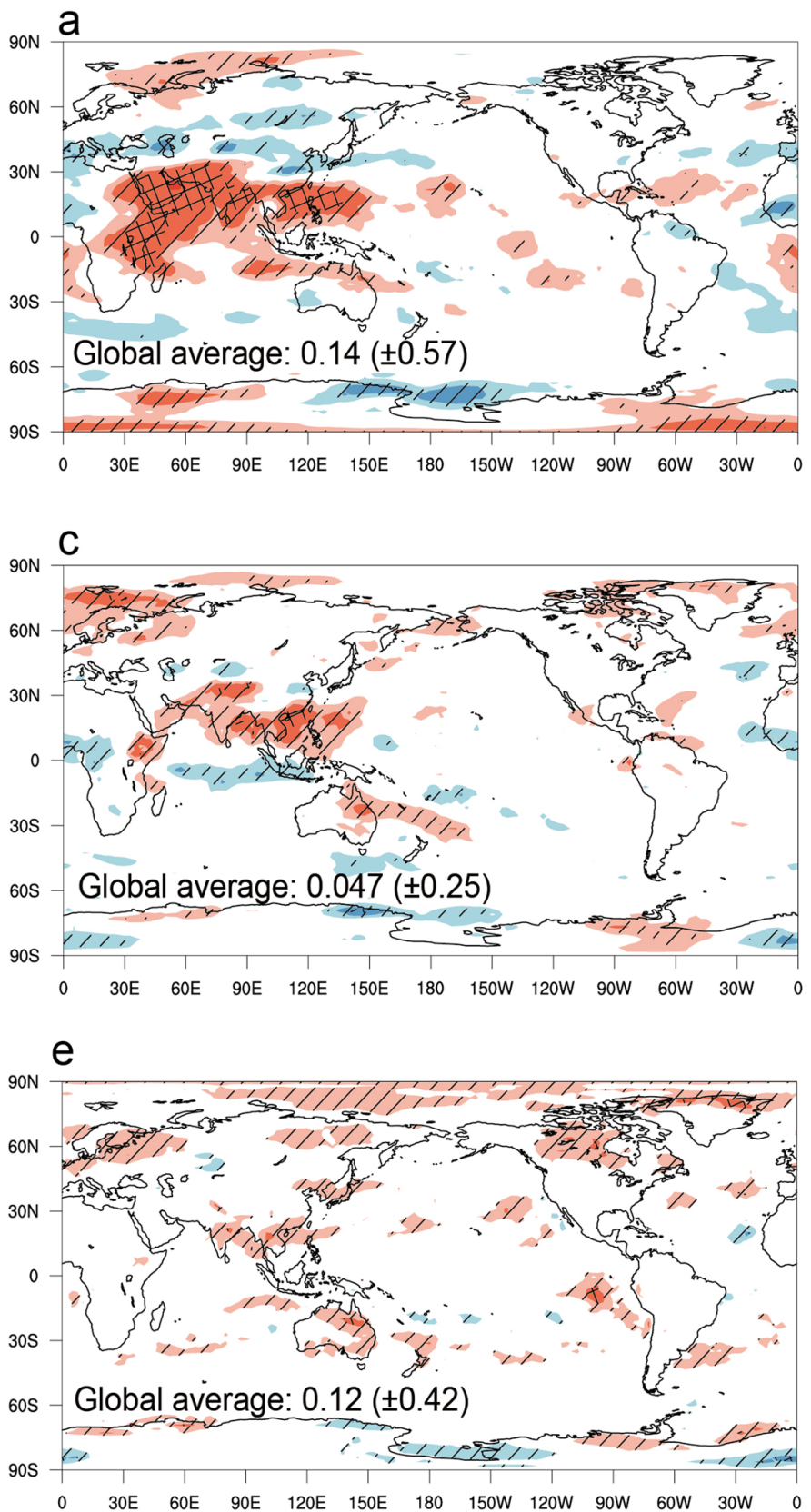

\section{Due to $\mathrm{E}_{\mathrm{c}}$ of developed countries}
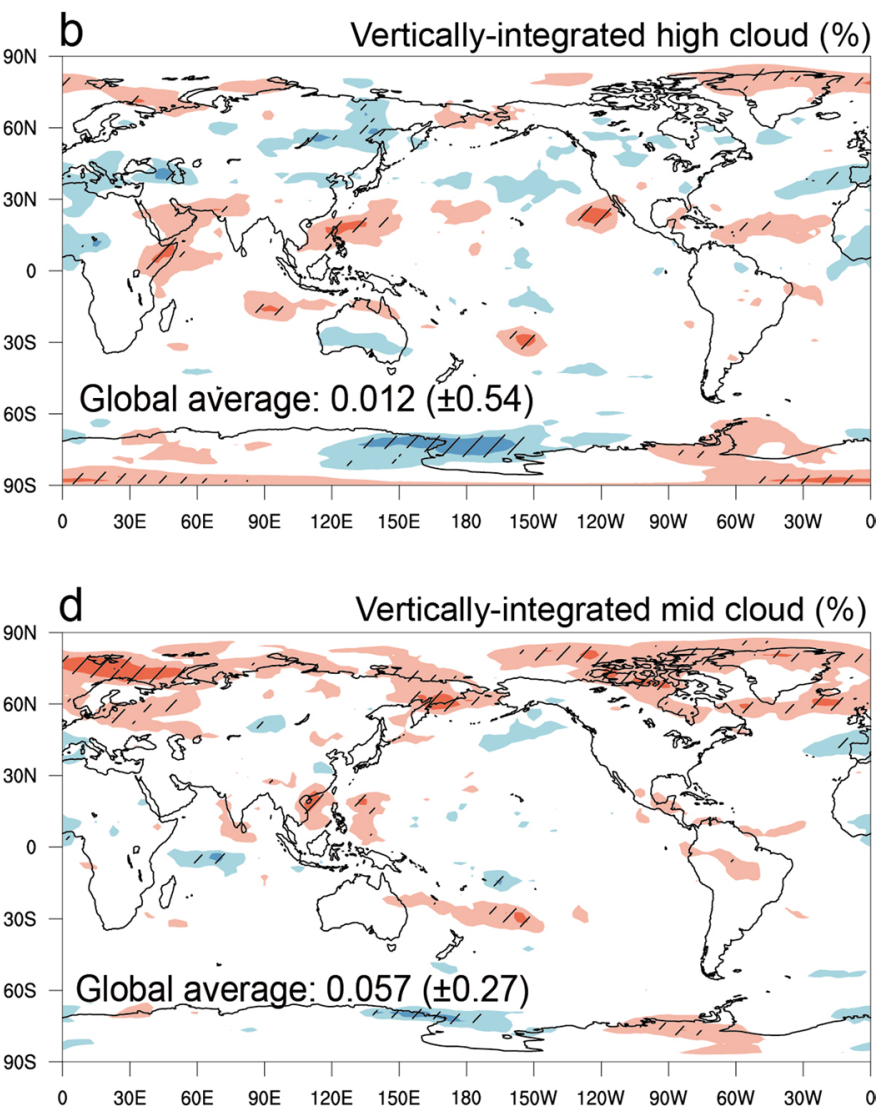

\begin{tabular}{ll|lll|l|l|l|lll}
\hline & & & & & & & & & & \\
\hline-7 & -5 & -3 & -1 & -0.5 & 0.5 & 1 & 3 & 5 & 7
\end{tabular}

Extended Data Fig. 4 | Fast adjustment of cloud coverage induced by consumption-based emissions in CAM6 simulations. Changes in annual mean high clouds (cloud top pressure $<400 \mathrm{hPa}$ ), mid clouds $\left(700-400 \mathrm{hPa}\right.$ ) and low clouds ( $>700 \mathrm{hPa}$ ) due to $\mathrm{E}_{\mathrm{c}}$ of developing and developed countries. The grid cells with cross lines pass the paired z-test at $95 \% \mathrm{Cl}$ and those with diagonal lines pass the test at $68 \% \mathrm{Cl}$. The global average with 2 standard deviations is shown in each panel. 


\section{Due to $E_{c}$ of developing countries}
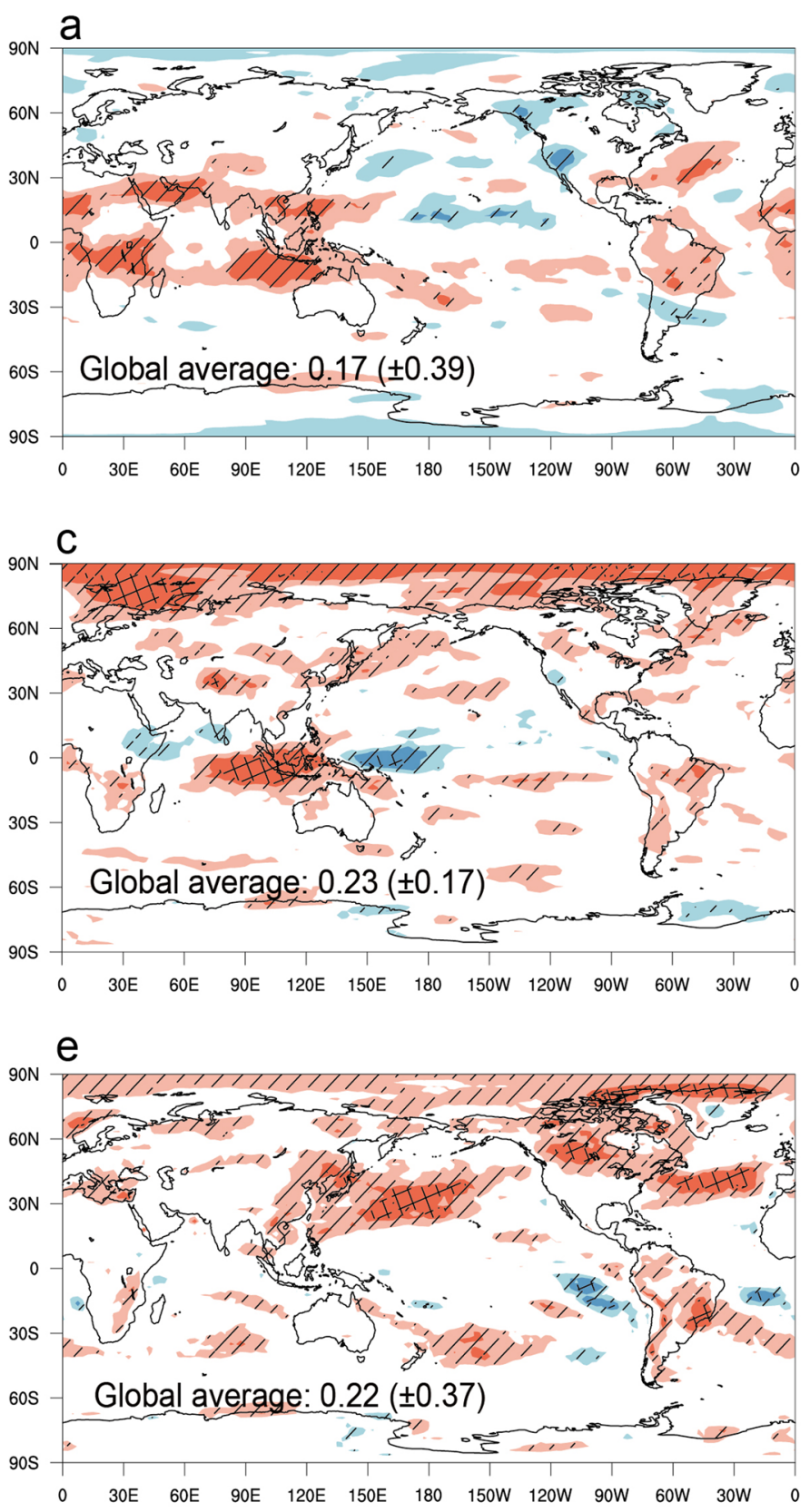

\section{Due to $E_{c}$ of developed countries}
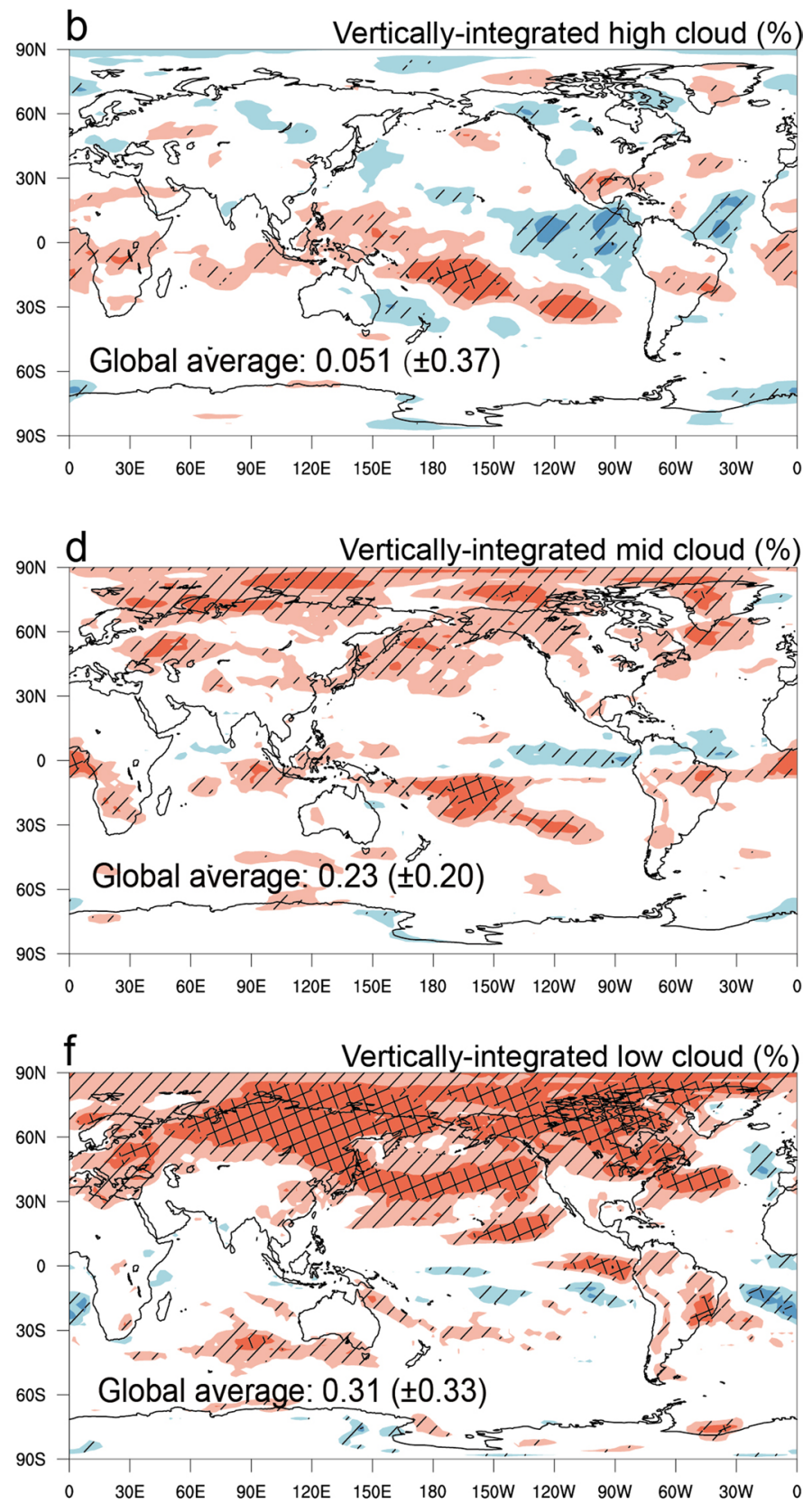

\begin{tabular}{|ll|l|l|l|l|l|l|l|l|}
\hline & & & & & & & & & \\
\end{tabular}

Extended Data Fig. 5 | Response of cloud coverage to consumption-based emissions in fully coupled CESM2 simulations. Changes in annual mean high clouds (cloud top pressure $<400 \mathrm{hPa}$ ), mid clouds ( $700-400 \mathrm{hPa}$ ) and low clouds ( $>700 \mathrm{hPa}$ ) due to $\mathrm{E}_{\mathrm{c}}$ of developing and developed countries. The grid cells with cross lines pass the paired z-test at $95 \% \mathrm{Cl}$ and those with diagonal lines pass the test at $68 \% \mathrm{Cl}$. The global average with 2 standard deviations is shown in each panel. 


\section{Due to $E_{c}$ of developing countries}

\section{a}

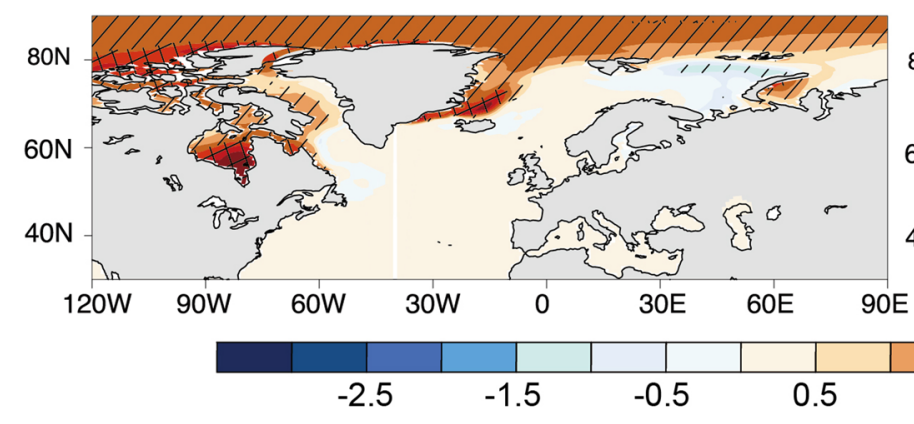

b

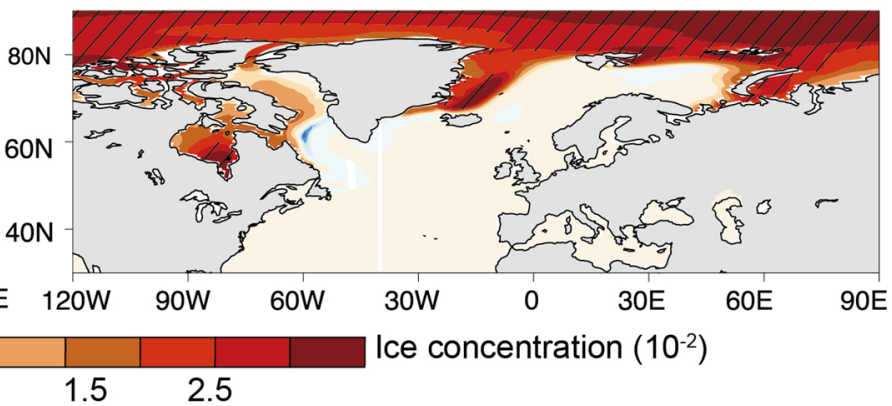

C

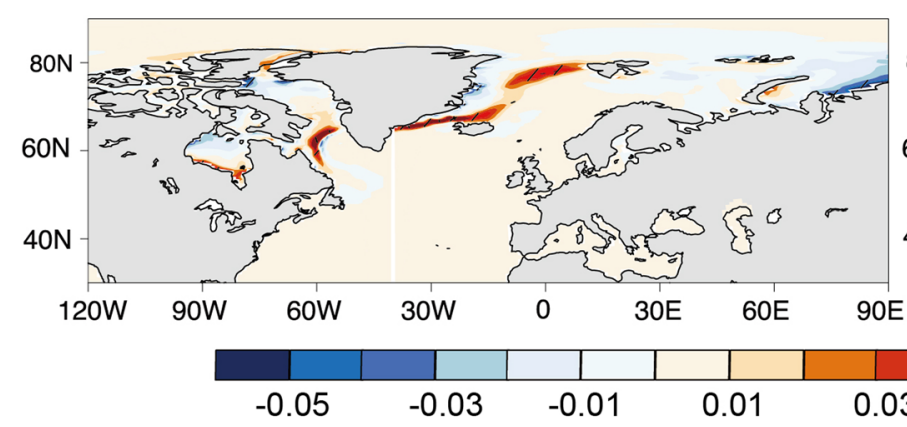

d

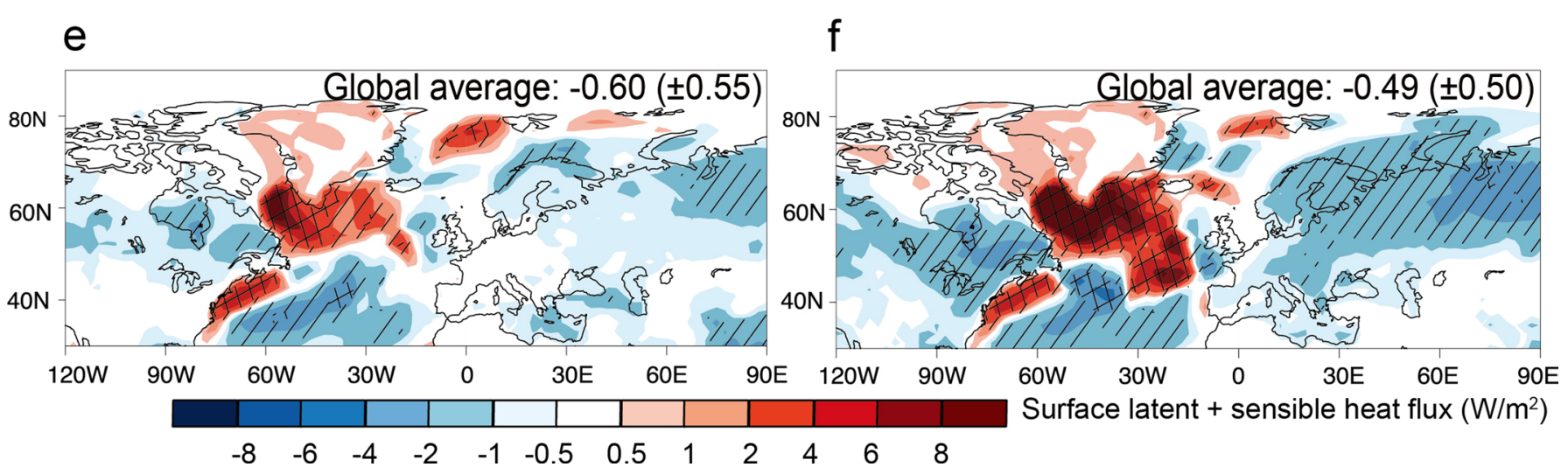

Extended Data Fig. 6 | Responses of sea ice and heat flux to consumption-based emissions. Changes in annual mean sea ice concentration (that is, fraction of the area covered by sea ice in each grid cell) $(a, b)$, wind-driven sea ice drift $(c, d)$ and surface heat flux (latent + sensible) (e, f) due to $E_{c}$ of developing and developed countries. The grid cells with cross lines pass the paired z-test at $95 \% \mathrm{Cl}$ and those with diagonal lines pass the test at $68 \% \mathrm{Cl}$. In e and $\mathrm{f}$, the global average of surface heat flux with 2 standard deviations is shown for comparison.

\section{Due to $\mathrm{E}_{\mathrm{c}}$ of developed countries}

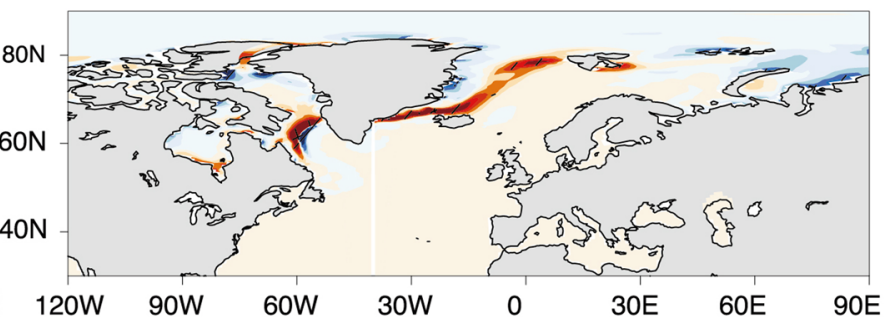

Ice thickness tendency due to ice drift (cm/day)

$03 \quad 0.05$


Due to $E_{c}$ of developing countries a

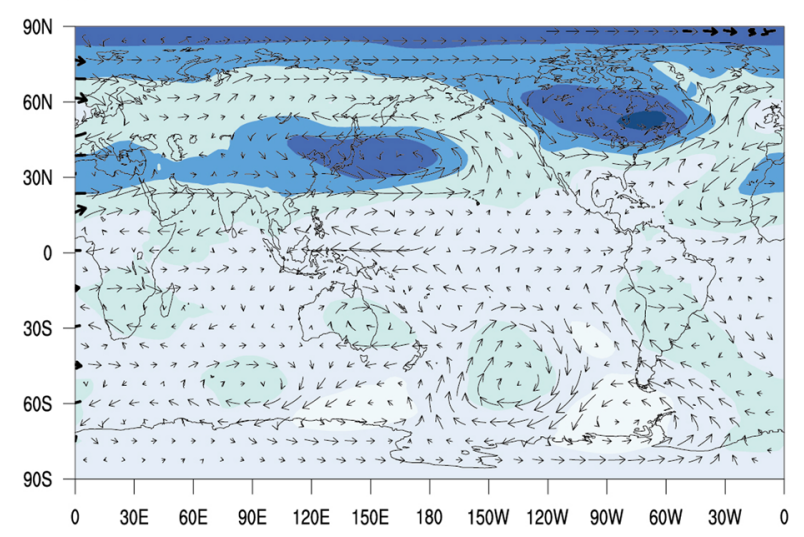

$\longrightarrow 500 \mathrm{hPa}$ wind $(0.5 \mathrm{~m} / \mathrm{s})$

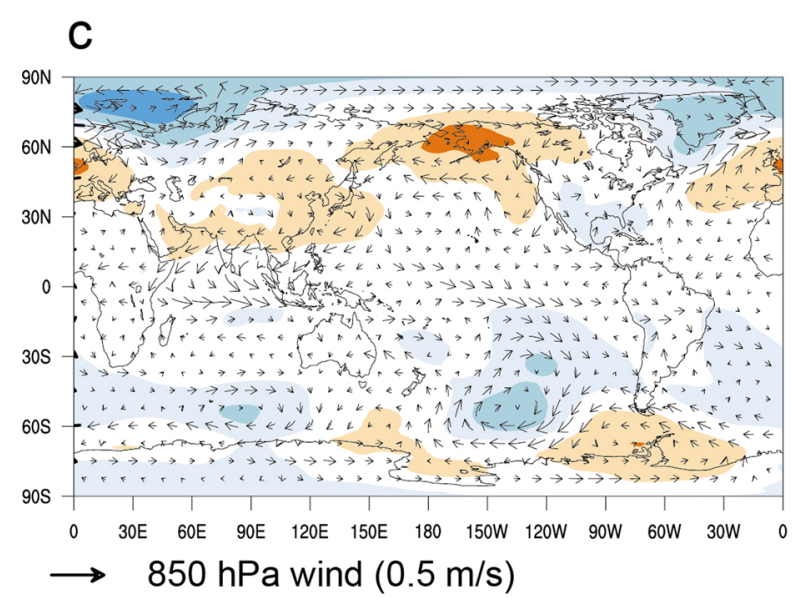

\section{Due to $E_{c}$ of developed countries}

b
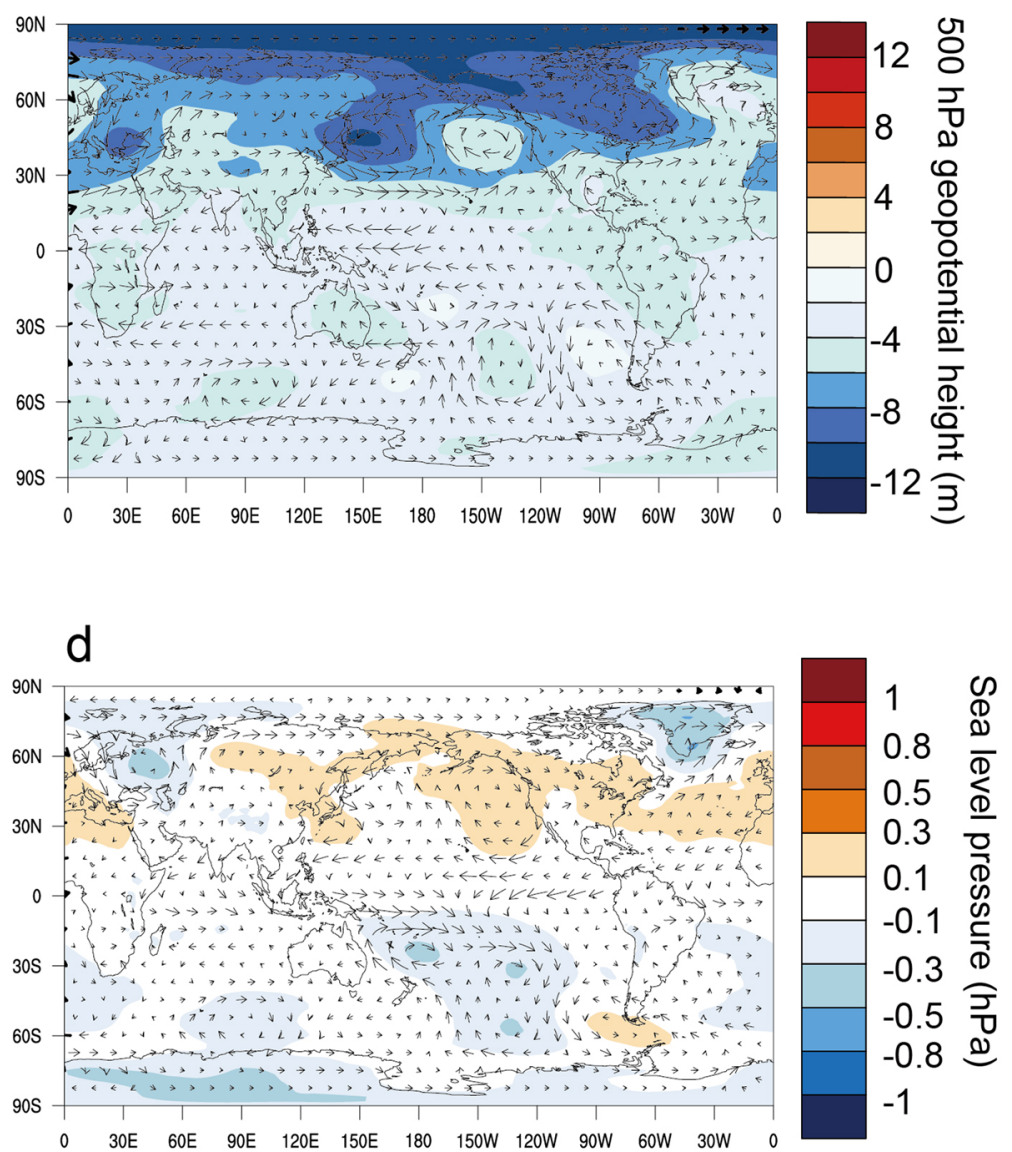

Extended Data Fig. 7 | Circulation response to consumption-based emissions. Changes in annual mean geopotential height (color, $\mathrm{m}$ ) and winds (vector) at $500 \mathrm{hPa}(\mathrm{a}, \mathrm{b})$ and changes in annual mean sea-level pressure (color, $\mathrm{hPa}$ ) and winds (vector) at $850 \mathrm{hPa}(\mathrm{c}, \mathrm{d})$ due to $\mathrm{E}_{\mathrm{c}}$ of developing and developed countries. 
Due to $\mathrm{E}_{\mathrm{c}}$ of developing countries

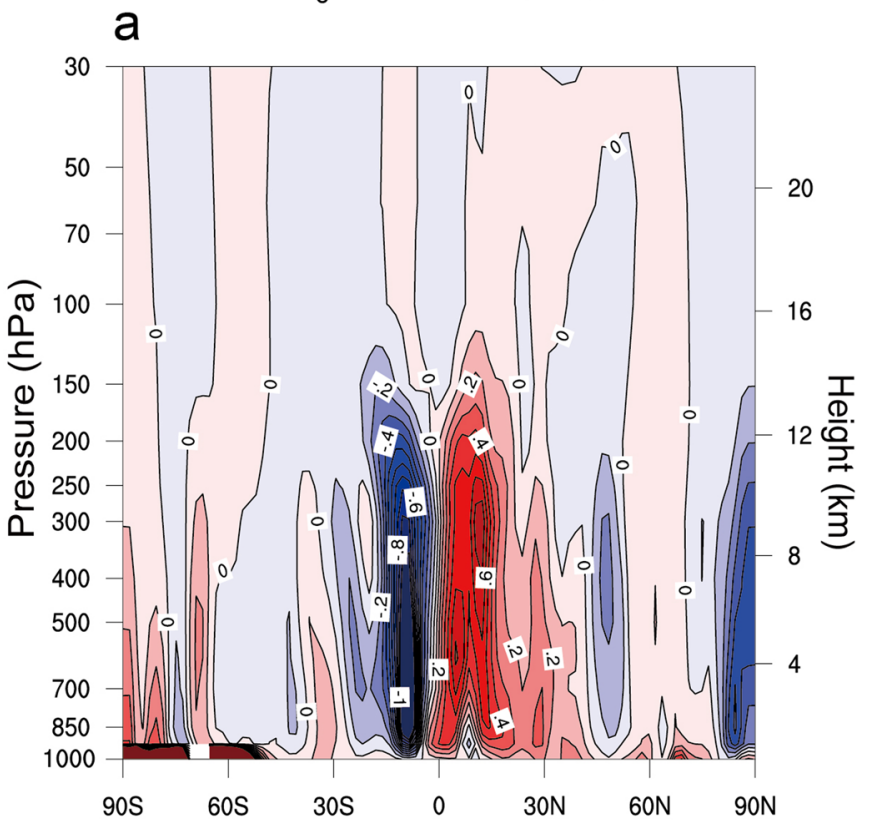

Due to $\mathrm{E}_{\mathrm{c}}$ of developed countries

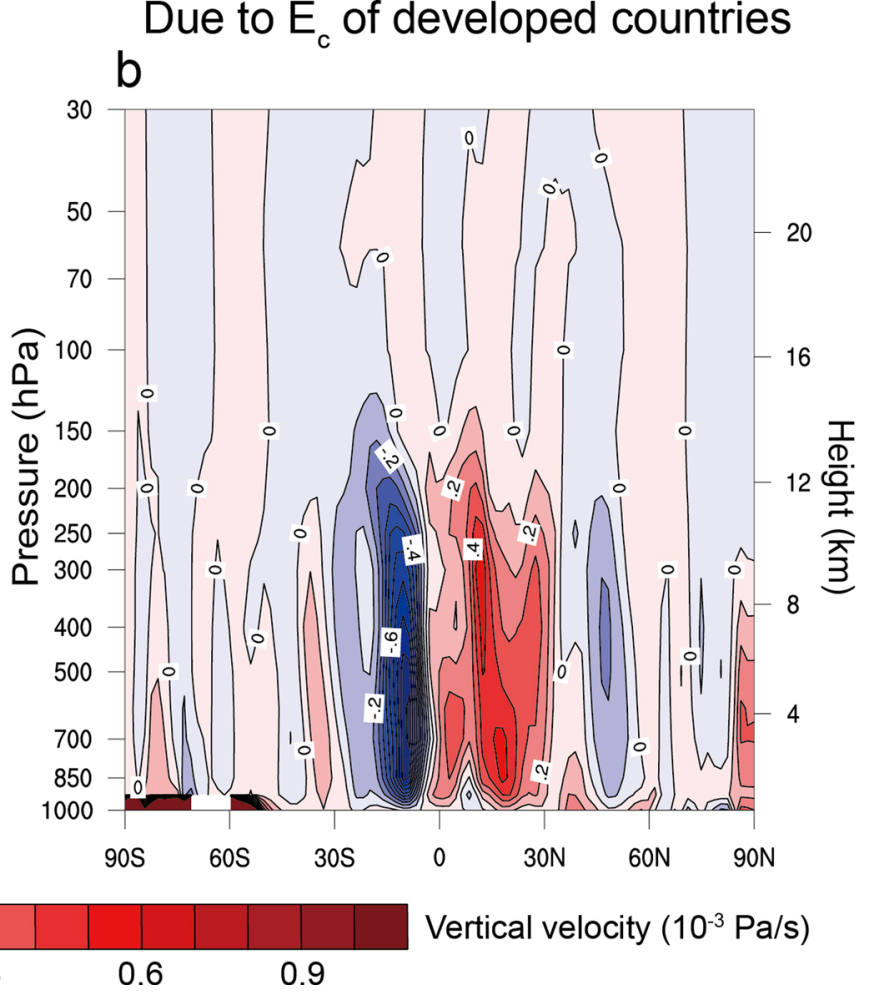

Extended Data Fig. 8 | Meridional circulation response to consumption-based emissions. Zonal average annual mean changes in vertical velocity $(\omega=d p / d t)$ due to $E_{c}$ of developing and developed countries. Negative values represent rising air. 
Extended Data Table 1 | Radiative kernel decomposition of Ec induced ERF. Factors contributing to the annual mean ERF include aerosol direct radiative forcing and fast adjustments of water vapor, surface albedo, temperature and clouds. Units are in $\mathrm{W} / \mathrm{m} 2$. The values in brackets represent 2 standard deviations

\begin{tabular}{|l|l|l|}
\hline & $\begin{array}{l}\text { Due to } \mathbf{E}_{\mathbf{c}} \text { of } \\
\text { Developing } \\
\text { countries }\end{array}$ & $\begin{array}{l}\text { Due to } \mathbf{E}_{\mathbf{c}} \quad \text { of } \\
\text { Developed } \\
\text { countries }\end{array}$ \\
\hline ERF & $-0.48( \pm 0.64)$ & $-0.42( \pm 0.64)$ \\
\hline Direct radiative forcing & $-0.16( \pm 0.031)$ & $-0.066( \pm 0.026)$ \\
\hline $\mathbf{H}_{2} \mathbf{O}$ & $0.036( \pm 0.19)$ & $0.010( \pm 0.19)$ \\
\hline Albedo & $-0.022( \pm 0.16)$ & $-0.040( \pm 0.17)$ \\
\hline Temperature & $-0.019( \pm 0.39)$ & $-0.007( \pm 0.41)$ \\
\hline Cloud & $-0.32( \pm 0.70)$ & $-0.32( \pm 0.72)$ \\
\hline
\end{tabular}


Extended Data Table 2 | Radiative kernel decomposition of Ec induced TOA net radiation flux in the fully coupled simulations. Factors contributing to the annual mean net radiation flux include ERF and the responses of water vapor, surface albedo, temperature and clouds. The contributions of all non-ERF factors are in addition to the radiative effects of their fast adjustments presented in Extended Data Table 1. Units are in $\mathrm{W} / \mathrm{m} 2$. The values in brackets represent 2 standard deviations

\begin{tabular}{|l|l|l|}
\hline & $\begin{array}{l}\text { Due to } \mathbf{E}_{\mathbf{c}} \text { of } \\
\text { Developing } \\
\text { countries }\end{array}$ & $\begin{array}{l}\text { Due to } \mathbf{E}_{\mathbf{c}} \text { of } \\
\text { Developed } \\
\text { countries }\end{array}$ \\
\hline TOA net radiation flux & $-0.073( \pm 0.50)$ & $-0.12( \pm 0.55)$ \\
\hline ERF & $-0.48( \pm 0.64)$ & $-0.42( \pm 0.64)$ \\
\hline HoO & $-0.26( \pm 0.94)$ & $-0.32( \pm 1.20)$ \\
\hline Temperature & $-0.046( \pm 0.13)$ & $-0.060( \pm 0.13)$ \\
\hline Cloud & $0.62( \pm 1.54)$ & $0.61( \pm 1.91)$ \\
\hline
\end{tabular}

